\title{
Clot Composition Analysis as a Diagnostic Tool to Gain Insight into Ischemic Stroke Etiology: A Systematic Review
}

\author{
Alicia Aliena-Valero, ${ }^{\mathrm{a}, *}$ Júlia Baixauli-Martín, ${ }^{\mathrm{b}, *}$ Germán Torregrosa, ${ }^{\mathrm{a}}$ José I. Tembl, ${ }^{\mathrm{c}}$ Juan B. Salom ${ }^{\mathrm{a}, \mathrm{b}}$ \\ aJoint Cerebrovascular Research Unit, La Fe Health Research Institute, University of Valencia, Valencia, Spain

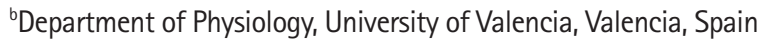 \\ 'Stroke Unit, Neurology Service, La Fe University and Polytechnic Hospital, Valencia, Spain
}

\begin{abstract}
Mechanical thrombectomy renders the occluding clot available for analysis. Insights into thrombus composition could help establish the stroke cause. We aimed to investigate the value of clot composition analysis as a complementary diagnostic tool in determining the etiology of large vessel occlusion (LVO) ischemic strokes (International Prospective Register of Systematic Reviews [PROSPERO] registration \# CRD42020199436). Following the Preferred Reporting Items for Systematic Reviews and Meta-Analyses (PRISMA) guidelines, we ran searches on Medline (using the PubMed interface) and Web of Science for studies reporting analyses of thrombi retrieved from LVO stroke patients subjected to mechanical thrombectomy (January 1, 2006 to September 21, 2020). The PubMed search was updated weekly up to February 22, 2021. Reference lists of included studies and relevant reviews were hand-searched. From 1,714 identified studies, 134 eligible studies (97 cohort studies, 31 case reports, and six case series) were included in the qualitative synthesis. Physical, histopathological, biological, and microbiological analyses provided information about the gross appearance, mechanical properties, structure, and composition of the thrombi. There were non-unanimous associations of thrombus size, structure, and composition (mainly proportions of fibrin and blood formed elements) with the Trial of Org 10172 in Acute Stroke Treatment (TOAST) etiology and underlying pathologies, and similarities between cryptogenic thrombi and those of known TOAST etiology. Individual thrombus analysis contributed to the diagnosis, mainly in atypical cases. Although cohort studies report an abundance of quantitative rates of main thrombus components, a definite clot signature for accurate diagnosis of stroke etiology is still lacking. Nevertheless, the qualitative examination of the embolus remains an invaluable tool for diagnosing individual cases, particularly regarding atypical stroke causes.
\end{abstract}

Correspondence: Juan B. Salom Joint Cerebrovascular Research Unit, La Fe Health Research Institute, University of Valencia, Torre A, Lab 5.05, Ave., Fernando Abril Martorell 106, 46026 Valencia, Spain

Tel: $+34-961246633$

Fax: +34-961246620

E-mail:salom_jba@gva.es https://orcid.org/0000-0002-4162-6101

Received: June 28, 2021

Revised: August 24, 2021

Accepted: September 2, 2021

*These authors contributed equally to the manuscript as first author.

Keywords Ischemic stroke; Thrombectomy; Cerebral thrombus; Etiology; Systematic review

\section{Introduction}

Mechanical thrombectomy has not only become the standard of care in the management of most large vessel occlusion (LVO) strokes, but it also renders the occluding clot available for lab bench analysis. ${ }^{1}$ Insights into thrombus composition and properties could help determine its relationships with the clot signs on imaging, stroke cause, resistance to thrombectomy, proce- 
dural complications, and outcome measures. ${ }^{2}$

A previous systematic review of studies published between January 2005 and December 2015 on imaging and histologic characteristics of thrombi in acute ischemic stroke (AIS) concluded that the hyperdense artery sign was associated with red blood cell (RBC)-rich thrombi and improved recanalization rates. However, there was no association between the histopathological characteristics of thrombi, stroke etiology, and angiographic outcomes. ${ }^{3}$ Another recent scoping systematic review focused on the impact of thrombus composition on the efficacy of mechanical thrombectomy and thrombolysis. ${ }^{4}$ However, assessing the value of clot analysis in the diagnosis of stroke etiology and thus guiding secondary prevention strategies seems more challenging.

This systematic review aimed to evaluate the value of clot composition analysis as a complementary diagnostic tool in determining the LVO ischemic stroke etiology. Specifically, we addressed the following research questions: (1) What types of physical, histological, or other biological analyses have been carried out on thrombi retrieved from LVO stroke patients subjected to mechanical thrombectomy?; (2) What kind of information about the structure, and molecular and cellular composition of stroke thrombi has resulted from laboratory analyses?; (3) Could laboratory analyses of clot structure and composition be used as complementary diagnostic tools to determine stroke etiology, and thus reduce the proportion of cryptogenic strokes?; (4) Could specific findings in clot composition be used as ancillary information to diagnose atypical stroke etiologies due to underlying pathologies?

\section{Methods}

The data supporting the findings of this study are available from the corresponding author upon reasonable request.

\section{Systematic review}

This systematic review was carried out according to Preferred Reporting Items for Systematic Reviews and Meta-Analyses (PRISMA) guidelines. ${ }^{5}$ The protocol was registered in the CRDNIHR International Prospective Register of Systematic Reviews (PROSPERO) with registration number CRD42020199436. ${ }^{6}$

We searched the published literature reporting the analysis of thrombi retrieved from LVO stroke patients subjected to mechanical thrombectomy and performed a qualitative assessment of the available evidence.

\section{Literature search strategy}

We carried out electronic searches on Medline (using the
PubMed interface) and Web of Science from January 1, 2006, up to and including September 21, 2020. The search syntax was (stroke AND (thrombus OR thrombi OR clot)) AND (thrombectomy OR endovascular). The search fields were [Title/Abstract] in Medline (PubMed) and [Topic] in Web of Science. There were no language restrictions. The PubMed search was updated weekly through My NCBI up to February 22, 2021. References were added to a Mendeley Reference Manager library dedicated to this review's topic, checked for duplicates, and completed with Mendeley's feedback-delivering personalized suggestions for related articles. Reference lists of included studies and relevant reviews were hand-searched. The electronic database search was supplemented by searching for trial protocols through ClinicalTrials.gov Advanced Search syntax: condition or disease (ischemic stroke) and other terms ((thrombus OR thrombi OR clot) AND (thrombectomy OR composition)). The search was not extended to unpublished studies or other sources of grey literature.

\section{Study selection: eligibility criteria and screening process}

The current review considered observational cohort studies, case series and case report studies reporting any kind of physical, histological, or other biological analyses carried out on thrombi retrieved from LVO stroke patients subjected to mechanical thrombectomy. We included studies published as full-length original research articles in any language, provided that the English abstract was available, and abstracts of conference proceedings in English language. In cases of studies with duplicate or overlapping patient populations, only the publication with the most complete dataset was included. Protocol articles, review articles and abstracts later published in full were also excluded.

Titles and abstracts yielded by the search were independently screened against the inclusion criteria by two reviewers. Full reports were obtained for all titles that appeared to meet the inclusion criteria or where there was any uncertainty. Reviewer pairs then screened the full-text reports of potentially eligible studies and decided whether these met the inclusion criteria. Disagreements were resolved through discussion and consensus involving a third reviewer.

\section{Data extraction and synthesis}

The following information was collected from the eligible studies and extracted to tables independently by two reviewers: general information (first author name, year of publication, source, and type of study), type(s) of physical, histological, or other biological analyses carried out on thrombi, sample size(s), qualitative and quantitative features about thrombus composi- 
tion, and diagnostic information regarding typical LVO ischemic stroke Trial of Org 10172 in Acute Stroke Treatment (TOAST) etiologies or atypical etiologies with underlying pathologies.

Heterogeneity in study design, outcome measuring, and reporting precluded a meta-analysis of the association between thrombus composition and typical or atypical stroke etiology. Instead, a systematic narrative synthesis is provided with information presented in the text and tables to summarize and explain the characteristics and findings of the included studies.

\section{Results}

\section{Search results: study selection and characterization}

A detailed study selection flow chart is shown in Figure 1. Briefly, a total of 2,665 records were identified electronically in the Web of Science and Medline (through PubMed) databases up to and including September 21, 2020. After removing duplicate and irrelevant records, and adding relevant records identified through an updated search on PubMed (up to and including February 22, 2021) and other sources, 152 full-text articles and congress abstracts were assessed for eligibility. Subsequent reasoned exclusions rendered 134 studies which were included in the qualitative synthesis (Supplementary Table 1).

A summary of the study characteristics is shown in Table 1.

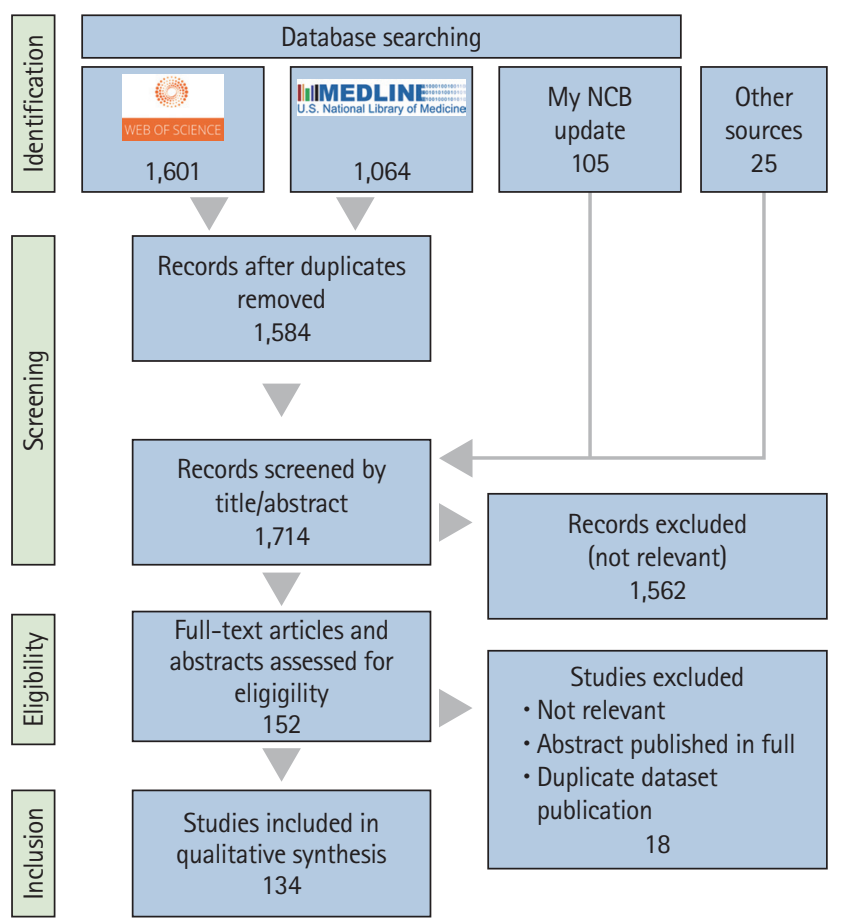

Figure 1. Preferred Reporting Items for Systematic Reviews and MetaAnalyses (PRISMA) flowchart of the literature search results and selection of studies at each stage.
Most of them (72.39\%) were observational cohort studies with a wide range of cohort sizes, varying from four to $1,022 \mathrm{pa-}$ tients with thrombus samples subjected to analysis (median, 65 [interquartile range, IQR, 37 to 105]). Thirty-one (23.13\%) case reports and six (4.48\%) case series were also included. In 108 out of the 134 studies, the retrieved thrombi were subjected to one or more types of histopathological examinations. Physical, biological, and/or microbiological analyses were carried out in 62 studies. A relationship between thrombus structure/composition and TOAST or atypical etiologies was reported in $54.48 \%$ of the studies. In $46.27 \%$ of the studies, the stroke etiology was not taken into consideration, or non-conclusive results were obtained.

The publication chronology of the studies is shown in Figure 2. Although Marder's pioneering study was published 15 years ago, ${ }^{7} 75.37 \%$ of the studies have been published in the last 5 complete years (2016 to 2020). Of note, $80 \%$ of the studies assessing thrombus composition by means of biological analyses using biochemical or molecular biology techniques have been published in the last 3 complete years (2018 to 2020). Since 11 studies have been published in 2021 up to and including February 22 , around 75 studies are estimated to be published in the present year.

The search for clinical trial protocols identified five ongoing studies in which thrombi and blood samples are being collected for histopathological and/or other biological analyses. ${ }^{8-12}$ Concurrently, active multi-institutional registries like RESTORE

Table 1. Study characteristics summary

\begin{tabular}{lc}
\hline Variable & No. (\%) \\
\hline All study types & $134(100)$ \\
Cohort & $97(72.39)$ \\
Case report (1-2 patients) & $31(23.13)$ \\
Case series (3-6 patients) & $6(4.48)$ \\
Histopathology & $108(80.60)$ \\
Conventional & $101(75.37)$ \\
Immunohistochemistry & $45(33.58)$ \\
Electron microscopy & $6(4.48)$ \\
Other analyses & $62(46.27)$ \\
Physical (macroscopic, mechanical, etc.) & $33(24.63)$ \\
Biological (biochemical, biomolecular, etc.) & $15(11.19)$ \\
Microbiological & $20(14.93)$ \\
Diagnostic & $73(54.48)$ \\
TOAST etiology & $32(23.88)$ \\
Atypical etiology/underlying pathology & $41(30.30)$ \\
None & $62(46.27)$ \\
\hline
\end{tabular}

TOAST, Trial of Org 10172 in Acute Stroke Treatment. 


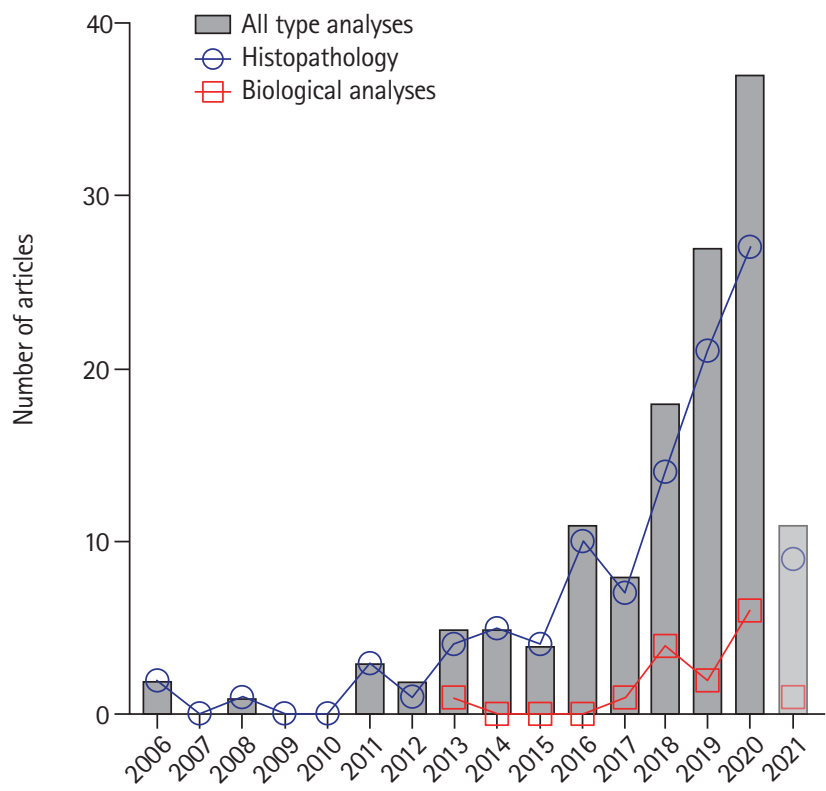

Figure 2. Chronology of study publication. Number of yearly-published studies from January 1, 2006, to February 22, 2021. Faded colors indicate incomplete year 2021.

(National University of Ireland) and Stroke Thromboembolism Registry of Imaging and Pathology, Mayo Clinic (STRIP) are compiling clinical, procedural, imaging, and histopathological data from patients with AIS.

\section{Types of physical, histological, and other} biological analyses

Procedures for thrombus retrieval and subsequent analysis have been reviewed. ${ }^{1,13}$ Briefly, after retracting the thrombectomy device, the retrieved clot material is gently removed from the device and transferred into saline solution. If clot per-pass analysis is desired, clot material from each pass can be processed separately. The macroscopic appearance and other physical properties of the retrieved thrombus can be freshly examined; otherwise, the clot can be flash-frozen for storage and later biological analyses. For histological analysis, the specimens are fixed, paraffin-embedded, sectioned, and stained depending on the component of interest. Both manual quantifications and color-based segmentation analysis of thrombus components are used.

Supplementary Table 1 summarizes whether physical, histological, or biological analyses were carried out in each of the 134 included studies. ${ }^{7}{ }^{714-146}$

In 33 studies, thrombi were subjected to some kind of physical analysis. The gross appearance of the retrieved thrombus was reported in 29 studies. In case reports (20 studies) and case series (two studies), the macroscopic aspect of the thrombus was shown mostly through photographs. Mechanical be- havior of the thrombi was analyzed in two studies using custom-made platforms and marketed devices, respectively. In one study the thrombi were scanned using high spatial-resolution three-dimensional (3D) T1-weighted magnetic resonance imaging (MRI) to reveal morphological and other physical characteristics. Finally, advanced synchrotron-based imaging techniques were used in one study to map thrombus composition.

Different types of histopathological examinations, including conventional histology, immunohistochemistry, and electron microscopy, were carried out in 108 studies. The most frequently used conventional stains were hematoxylin and eosin (H\&E, 86 studies), Martius Scarlet Blue (MSB, 18 studies), Elastica van Gieson (14 studies), Prussian blue (eight studies), Masson's trichrome (five studies), and Von Kossa (four studies). Other seldom-used stains were periodic-acid Schiff, Carstairs' staining, Picro-Mallory, Alcian blue, Luna, Mallory's phosphotungstic acid-hematoxylin, Ladewig trichrome, naphthol AS-D chloroacetate, and Feulgen's reaction. Immunohistochemistry was carried out in 45 studies with specific antibodies against cellular and biomolecular thrombus components. Finally, the thrombi composition and organization were analyzed at the ultrastructural level through electron microscopy in six studies.

Regarding biological analyses, thrombus composition was assessed through different biochemical, biomolecular, and cellular techniques, such as enzymatic assay, enzyme-linked immunosorbent assay (ELISA), transcriptomics (real-time reverse transcription polymerase chain reaction [qRT-PCR]), proteomics, metabolomics, and flow cytometry in 15 studies. Finally, microbiological analysis of the thrombi was performed through classical culture techniques, specific staining for bacteria/fungi and/or metagenomics (qPCR) in 20 studies.

\section{Thrombus gross appearance and mechanical properties}

Case reports and case series, usually presenting thrombectomies of LVOs of atypical etiologies, showed mostly photographic images of the thrombus, and described whether single or multiple clots were retrieved, as well as their gross appearance, including size, shape, consistency, visual texture, color, and homo/heterogeneous aspect. ${ }^{14-34}$

Macroscopic analysis of retrieved thrombi was also carried out in some cohort studies and one case series. The clot color was categorized using three different terminologies. Two cohort studies classified the thrombus as "red-black" or "white," showing similar results: $94.2 \%$ red-black thrombi versus 5.8\% white thrombi, ${ }^{35}$ and $91.4 \%$ red/black thrombi versus $8.6 \%$ white thrombi. ${ }^{36}$ Another cohort study categorized the thrombi by visual assessment as pinkish (17.3\%), red (53.8\%), or dark 
Table 2. Average proportions of fibrin and blood formed elements in stroke thrombi

\begin{tabular}{lccccc}
\hline PLT & FBR & PLT+FBR & RBC & WBC & Reference \\
\hline $59 \% \pm 138 \%, 166$ & $41 \% \pm 25 \%, 166$ & & $38 \% \pm 25 \%, 166$ & $4 \% \pm 5 \%, 166$ & $56,57,67,72$ \\
& & $52 \% \pm 19 \%, 1,025$ & $41 \% \pm 19 \%, 1,045$ & $5 \% \pm 3 \%, 944$ & $38,8,84,92,122,142-146$ \\
$27 \% \pm 16 \%, 287$ & $38 \% \pm 37 \%, 287$ & & $41 \% \pm 91 \%, 287$ & & $54,55,64,65,123$ \\
& & $52 \% \pm 25 \%, 441$ & $47 \% \pm 25 \%, 441$ & & $78,87,101$ \\
\hline
\end{tabular}

Values are presented as weighted mean \pm pooled standard deviation or number.

PLT, platelet; FBR, fibrin; RBC, red blood cell; WBC, white blood cell.

red (28.8\%). ${ }^{37} \mathrm{~A}$ fourth cohort study described the thrombi as slightly white, darker, or reddish, but did not report percentages. ${ }^{38}$ Regarding thrombus size, other cohort studies focused on the total extracted clot area (ECA) for each case, defined as the sum of the clot areas from all clot fragments within a case..$^{39}$ In a cohort of 550 patients, the mean ECA for all cases was 64 $\mathrm{mm}^{2}$ and the median number of fragments per case was $3{ }^{40}$ Of note, bridging therapy was associated with the retrieval of significantly smaller clots. ${ }^{41,42}$ Median ECA was $0.33 \mathrm{~cm}^{2}($ IQR, 0.16 to 0.59 ) in patients pre-treated with alteplase (recombinant tissue plasminogen activator [rtPA]), versus $0.39 \mathrm{~cm}^{2}$ (IQR, 0.22 to 0.82 ) in patients treated with mechanical thrombectomy alone. ${ }^{41}$ Finally, in a case series of five patients the median volume of the thrombus, calculated using the ellipsoid formula $\left(4 / 3 \pi r_{1} r_{2} r_{3}\right)$, was $10.47 \mathrm{~mm}^{3.3}$

Only two studies with limited sample sizes evaluated the mechanical behavior of the thrombi. The specimens were mechanically heterogeneous, in line with the histological heterogeneity. Stiffness and elasticity were measured with a dynamic mechanical analyzer, showing that red thromboemboli composed mainly of fibrin (FBR) and RBC were much softer than the calcified and cholesterol-rich material. ${ }^{44}$ The tensile strength and response to stress were measured with a quasistatic uniaxial tensile test using a custom-made platform. The ultimate tensile strain of the emboli increased with a higher platelet (PLT) percentage, and the ultimate tensile stress increased with a higher FBR percentage and decreased with a higher RBC percentage. ${ }^{45}$

\section{Thrombus structure and composition: advanced imaging and histopathology}

Multiparametric MRI has been used to characterize retrieved cerebral thrombi. Preliminary results showed that $\mathrm{T}_{1}$-weighted images with the corresponding apparent diffusion coefficient (water mobility) and $\mathrm{T}_{2}$ maps (relaxation time) could be used to assess thrombus compactness and microstructure, which in turn reflect RBC and PLT/FBR meshwork content. ${ }^{46}$ Advanced synchrotron-based imaging techniques, including $X$-ray fluorescence and Fourier-transform infrared spectroscopy, have been used in freshly retrieved thrombi to map the distribution of biological elements and metabolites, respectively. ${ }^{47}$

Most histopathology studies focused on the presence and relative abundance of FBR, and blood formed elements (RBCs, PLTs, and white blood cells [WBCs]) in the thrombus. Classical H\&E staining was almost always used to visualize the general structure of the thrombus. Although H\&E staining and machine learning software allowed reproducible quantification of the three major clot components (RBCs, WBCs, and FBR) ${ }_{1}^{48}$ the more specific MSB staining was used in many studies for the selective quantification of RBCs and FBR. .8,37,39,43,44,49-61 $^{2}$ The Picro-Mallory stain was used to assess the maturity of FBR in thrombi, based on its age-dependent differential staining. ${ }^{62}$ Immunohistochemical staining procedures allowed the best visualization and reliable separate quantification of RBCs (glycophorin $\mathrm{A}$, also designated CD235a antigen), ${ }_{1}^{63-65}$ WBCs (CD45 antigen), ${ }^{66-70}$ PLTs (CD41, CD42b, and CD61 antigens) ${ }_{1}^{38,45,49,51,53,56,57,60,63,65,66,71-73}$ and fibrinogen/FBR. ${ }^{49,53,63,65,66,74}$ Depending on the discriminatory capability of the staining procedures used, the studies expressed the ratios of clot components according to four different classifications, as shown in Table 2. A number of studies categorized the clots according to the dominant component (usually with a $60 \%$ cut-off) ${ }^{48}$ as RBCrich, FBR-rich, PLT-rich, or mixed. ${ }^{7,50,52,54,58,59,64,75-91}$ Some studies identified and/or quantified WBC types and subtypes by immunohistochemical staining using specific antibodies against neutrophil elastase (NE), ${ }^{66,76,92-94}$ neutrophil myeloperoxidase (MPO), ${ }^{65,66,76,95}$ Ly6G (monocyte, granulocyte, and neutrophil), ${ }^{94}$ CD3 (T lymphocyte), ${ }_{1}^{66,68-70,90,96}$ CD4 (T lymphocyte), ${ }^{52,53}$ CD14 (monocyte), ${ }^{66} \mathrm{CD} 15$ (neutrophil, eosinophil, and monocyte), ${ }_{1}^{97}$ CD20 (B lymphocyte), ${ }^{66,68-70,96}$ CD66b (neutrophil), ${ }^{76,93}$ and CD68 (monocyte and macrophage). ${ }^{30,52,67-70,96,98}$

Neutrophils were the predominant leukocyte subset in stroke thrombi. ${ }^{6693}$ Neutrophil extracellular traps (NETs) have been identified as part of the clot scaffold by using antibodies against NETosis biomarkers (citrullinated histones) and histochemical staining of extracellular DNA. ${ }^{63,65,66,76,93-95,99}$ NETs were visualized in almost all (79.1\% to 100\%) of the analyzed thrombi in different studies, ${ }_{1}^{63,65,66,76,93,95}$ in amounts ranging 
from $0.21 \%$ to $13.45 \%$ of total thrombus area, ${ }^{93}$ and $1.1 \% \pm 2.7 \%$ on average. ${ }^{76}$ NET signals were observed as being confined within cells, filopodia-like structures, or web-like structures, ${ }_{1}^{65}$ especially in the outer thrombus layers, ${ }^{63,95}$ and almost exclusively within FBR-rich areas. ${ }^{76}$ Inside the NETs, citrullinated histones were co-localized with inflammasome proteins (caspase-1 and apoptosis-associated speck-like protein containing a caspase-recruitment domain [ASC]), ${ }^{99}$ granular neutrophil proteins (MPO) and extracellular DNA released from neutrophils. ${ }^{93,95}$ The addition of histone-DNA complexes to FBR resulted in thicker fibers accompanied by increased rigidity, which contributed to the structural complexity and stabilization of the thrombi. ${ }^{76}$ Of interest, monocytes could also form extracellular traps, but to a lesser extent than neutrophils. ${ }^{66,94}$

Coagulation system proteins other than fibrinogen/FBR were immunohistochemically identified by using specific antibodies against von Willebrand factor (VWF) ${ }_{1}^{52-56,60,63,74,97,100}$ and two PLTderived direct inhibitors of tissue plasminogen activator (tPA): plasminogen activator inhibitor- $1^{63,74}$ and protease nexin-1. ${ }^{63}$ The proportion of WWF varied from $0.1 \%$ to $94.3 \%$ of the total clot area, ${ }^{60}$ with mean values between $11.8 \%$ and $29.8 \%$ in different studies, ${ }^{56,60,100}$ and higher content in thrombi retrieved after unsuccessful intravenous thrombolysis. ${ }^{74}$ VWF levels were correlated with those of FBR and PLTs. ${ }^{97}$ White FBR-rich thrombi showed higher percentages of VWF+ areas co-localized with regions of FBR/collagen. ${ }^{52}$ Similarly, PLT-rich areas were characterized by dense FBR structures aligned with $\mathrm{WWF}^{53}$

The presence of other thrombus components has been assessed using specific staining procedures. Some cohort studies used standard protocols including $\mathrm{H} \& \mathrm{E}$ and one or more of the following staining procedures to visualize elastic collagen fibers (Elastica van Gieson), hemosiderin/iron (Prussian blue), calcifications (Von Kossa), and collagen (Masson's trichro me). ${ }^{67-70,78,81,86,88,89,91,96,101}$ However, positive results showing the occasional presence of intimal collagen fibers, cholesterol clefts, and smooth muscle cells (immunohistochemically stained for a-smooth muscle actin) were reported only in three studies assessing thrombectomy-induced wall damage, which identified vascular wall components or atheromatous gruel in a low proportion (2.6\% to 20\%) of the retrieved thrombi. ${ }^{78,91,101}$ Case reports also used these specific stainings to identify elastic fibers, hemosiderin granules, collagen fibrous stalks, calcium deposits, and myofibroblast-like cells, usually in atypical thrombi. ${ }^{15,23,30,43,102}$

The presence of foreign bodies in thrombi has also been evaluated. Delaminated polymer coating particulates were readily detected in 33\% of H\&E-stained preparations. ${ }^{103}$ Thread or sheet-like structures were found in $25 \%$ of thrombi scanned by electron microscopy. ${ }^{104}$

Classical descriptions of thrombus histological patterns based on light microscopy categorized their organized structure as layered (PLT bands arranged in layers), serpentine (PLT bands arranged in a serpentine way), or erythrocytic (with RBCs and nucleated cells interspersed)., 75,75,105,106 The molecular and cellular organization revealed distinct features between clots as well as among different regions within a clot. Thrombi were composed of two main area types: RBC-rich and PLT-rich areas. RBC-rich areas had limited complexity and consisted of RBCs entangled in a meshwork of thin FBR. Conversely, PLT-rich areas were characterized by dense FBR structures aligned with VWF and abundant amounts of WBCs and DNA that accumulate around. ${ }^{53}$ Similarly, serial block-face scanning electron microscopy (SEM) showed a thrombus 3D ultrastructure that varied greatly depending on the region analyzed. RBC-rich areas were composed mainly of tightly packed RBCs deformed into polyhedrocytes with scant FBR fibers interwoven between cells. The regions with mixed composition showed thick FBR fibers along with PLTs, WBCs, and RBC clusters. FBR-rich areas contained dense FBR masses with sparse RBCs. ${ }^{56}$ High-resolution SEM and transmission electron microscopy revealed a dense, sealed, rtPA-resistant external shell encapsulating a loose RBC-rich core. Shell components were densely compacted and agglomerated and formed a continuous layer, in which individual cells could hardly be detected. This was in stark contrast to the clearly identifiable RBCs, FBR fibers, and aggregated PLTs in the inner core. ${ }^{63,107}$ Other ultrastructural studies showed morphologic features consistent with the presence of NETs, calcified deposits and cholesterol crystals in the clots. ${ }^{44,99}$

\section{Microbial pathogens in thrombi}

Regarding septic cerebral emboli, Marder's pioneering study reported one case of mycotic embolus. ${ }^{7}$ However, both realtime and standard PCR demonstrated no expression of bacterial $16 \mathrm{~S}$ rDNA in any of the 20 clot samples. Gram staining results also showed no evidence of bacteria. ${ }^{108}$ Contrastingly, bacteria were detected in Gram-stained clots of four out of 65 patients (6.2\%). ${ }^{109} \mathrm{~A}$ larger cohort of 75 patients showed DNA signatures of oral streptococcal bacteria in $84 \%$ of the retrieved thombi. ${ }^{110}$ Metagenomics analysis also showed the presence of bacterial DNA in all four thrombi originated from symptomatic carotid plaques. ${ }^{111}$

\section{Thrombus composition: molecular biology,} biochemical assays, and flow cytometry

Clot homogenates subjected to qRT-PCR showed the expression 
of inflammatory cytokines (interleukin $1 \beta$ [IL-1ß], IL-6, IL-8, IL18 , tumor necrosis factor a [TNF- $\alpha$ ], and monocyte chemoattractant protein-1 [MCP-1]), matrix metalloproteinases-2, $-9{ }_{1}^{112}$ and endothelial CD31. ${ }^{75}$ Four-plex assay showed the expression of cytokines (IL-1 $\beta$ and IL-18) and other inflammasome signaling proteins such as caspase- 1 and ASC. Moreover, the presence of nucleotide-binding oligomerization domain (NOD)-like receptor protein-1 and absent in melanoma-2, two receptors that interact with caspase- 1 and ASC to form an inflammasome complex, was shown by immunoblot analysis..$^{99}$

Proteomic analysis has been used to characterize the protein cargo of thrombi (thousands) and commonly present proteins (hundreds). Functional bioinformatics analyses revealed protein clusters related to inflammation; ${ }^{113}$ immunological functions, blood cell dependent functions, and peripheral vascular processes ${ }_{1}^{114}$ metabolic processes, inflammatory track, and cell proliferation, activation, or motility; ${ }^{115}$ primary hemostasis, integrin and kinase signaling linked to integrins, glycolysis, and acute phase reactants. ${ }^{116}$ Nevertheless, metabolomics analysis suggested clot sorbitol content as a surrogate marker reflecting blood glucose level at stroke onset. ${ }^{117}$

PLT, RBC, and WBC content of AIS thrombi could be estimated through biochemical quantification of glycoprotein (GP) VI (immunoassay), heme (formic acid-based colorimetric assay), and DNA (dsDNA fluorescence assay kit) in thrombus homogenates. ${ }^{118}$ Hemoglobin (ELISA) and heme content were highly correlated with RBC content determined by flow cytometry. ${ }^{119}$ Different lymphocyte profiles were identified in cell suspensions of clots subjected to flow cytometry..$^{20}$

The presence of NETs was confirmed in intact thrombus samples subjected to endonuclease treatment to release NE activity, ${ }_{1}^{95}$ and by incubating with DNase-I to produce ex vivo thrombolysis. ${ }^{71}$ Thrombin elution pattern assessed by measuring secreted thrombin activity along serial washings has been suggested as a biomarker of clot content. ${ }^{121}$

\section{Relationship between thrombus features and stroke etiology}

Analysis of thrombus size, structure and composition in patient cohorts found associations with TOAST etiology (large-artery atherosclerosis [LAA; TOAST 1]; cardioembolism [CE; TOAST 2]; stroke of other determined cause [ODC; TOAST 4]; cryptogenic [CRY] stroke of undetermined etiology [TOAST 5]), embolic stroke of undetermined source (ESUS), or underlying pathologies (Supplementary Table 2). LAA thrombi showed a larger ECA ${ }^{39,40}$ and higher number of fragments..$^{40}$ Eight studies, reporting results from 1,183 thrombi (median 73), showed higher RBC proportions in thrombi from LAA or non-CE (LAA+ODC) sourc- es. ${ }^{39,57,64,82,96,122-124}$ Contrastingly, three studies (119 thrombi, median 37) showed higher RBC proportions in CE thrombi. ${ }^{72,84,125}$ Seven studies (1,061 thrombi, median 58) showed higher FBR proportions in $\mathrm{CE}_{1}^{39,57,76,82,96,123,124}$ while in two studies (82 thrombi, median 41) the FBR proportion was higher in LAA. ${ }^{72,125} \mathrm{CE}$ thrombi also showed a higher FP (FBR+PLTs) proportion in one study (137 thrombi). ${ }^{122}$ PLT proportion was higher in LAA in two studies $\left(1,127\right.$ thrombi, median 563.5) ${ }^{50,59}$ but higher in CE in another two studies (697 thrombi, median 348.5). ${ }^{39,67}$ Further support for higher PLT proportions in non-CE thrombi came from higher GP VI content in thrombus homogenates. ${ }^{118}$ LAA thrombi showed mostly peripheral PLT distribution patterns (PDPs), while mostly clustering PDP was observed in CE. ${ }^{51}$ NonCE thrombi showed higher RBC/PLT ratio, ${ }^{73}$ in line with lower FP/RBC ratio. ${ }^{126}$ Results from the large multicentric STRIP registry $(1,350$ thrombi), published during the preparation of this manuscript, showed that LAA thrombi had a higher mean RBC density $(46 \% \pm 23 \%$ vs. $42 \% \pm 22 \%, P=0.01)$ and a lower PLT density $(24 \% \pm 18 \%$ vs. $27 \% \pm 18 \%, P=0.03)$ than CE thrombi. ${ }^{147}$ Regarding WBCs, three studies (358 thrombi, median 137) showed higher proportions in $\mathrm{CE}_{1}^{89,96,122}$ while one study (37 thrombi) reported higher proportions in LAA ${ }^{84}$ Another study supported higher WBC proportions in CE, as estimated by DNA content in thrombus homogenates. ${ }^{118}$ When WBC subtypes were analyzed, CE thrombi showed higher contents of neutrophils, ${ }^{76}$ $\mathrm{NETs}_{1}{ }^{6,93}$ and netting neutrophils, ${ }^{66}$ as well as more macrophages. ${ }^{67}$ As for lymphocytes, CE thrombi contained more suppressor-cytotoxic T-cells, ${ }^{120}$ while LAA thrombi showed higher Tcell, ${ }_{1}^{90}$ helper T-cell, and natural killer (NK)-cell contents. ${ }^{120} \mathrm{Fi}-$ nally, higher IL-1 $\beta$ expression was measured in LAA thrombi, ${ }^{112}$ while coagulation factor XIII was associated with CE. ${ }^{115}$

Some studies aimed to compare the features of CRY thrombi with those of known TOAST etiology. Most of them found similar proportions of $\mathrm{RBCS}_{1}{ }^{39,57,64,96,122-124,127} \mathrm{FBR}$, PLTs (or both together), ${ }_{1}^{57,76,96,122-124,127}$ and WBCs between CRY and CE thrombi. ${ }^{96,122,127}$ CRY and CE thrombi also shared smaller ECA and number of retrieved fragments, ${ }_{1}^{39,40}$ clustering PDP $_{1}^{51}$ higher neutrophil counts, ${ }^{76}$ and NETosis, ${ }^{66}$ temporal profile of eluted thrombin activity, ${ }^{121}$ and low expression of IL- $1 \beta .^{112}$ ESUS and CE thrombi showed similar RBC/PLTs ratios. ${ }^{73}$ Conversely, a few studies found similar proportions of RBCs, ${ }^{84} \mathrm{PLTs}_{1}{ }^{50}$ and WBCs ${ }^{84,89}$ in CRY and LAA thrombi. Finally, ESUS and LAA thrombi shared low macrophage proportions. ${ }^{67}$

Regardless of TOAST etiology, some thrombus features have been associated with the patient's age and underlying pathologies. The clots from elderly subjects had higher FBR proportions compared to younger patients. ${ }^{128}$ As for gross appearance, white thrombi were much more frequent in the context of pa- 
thologies like active cancer (AC) or infective endocarditis (IE). ${ }^{36,38}$ Furthermore, thrombi showed lower RBC proportions, and higher FBR and/or PLT proportions, with underlying $\mathrm{AC}^{38,65}$ or diabetes mellitus (DM). ${ }^{55}$ Other composition characteristics were lower WBC proportion in $\mathrm{AC}_{1}^{38}$ and higher NETosis in DM. ${ }^{94}$ Direct presence of tumor cells in the thrombus was rare in $\mathrm{AC} .{ }^{129}$ Contrastingly, bacteria or fungi were present with underlying $\mathrm{IE}^{7,109}$ or other systemic infections. ${ }^{109}$

Thrombus analysis in individual cases was a valuable complementary tool in diagnosing the stroke etiology, especially atypical ones (Supplementary Table 3). Proteomic analysis determined a common origin for tandem occlusions after traumatic carotid thrombosis and embolization. ${ }^{130}$ Macroscopic and thorough histopathological examination confirmed the occlusion by an intracranial atherosclerotic plaque, revealing the atherothrombotic etiology. ${ }^{19}$ Identification of cocci or bacilli in the thrombus confirmed septic emboli in cases of bacterial $\mathrm{IE}_{1}{ }^{14,18,31,32,102,131-135}$ including a rare case of Whipple's endocarditis. ${ }^{26}$ Similarly, the presence of Candida confirmed septic embolus in a case of fungal IE. ${ }^{136}$ Observation of fungal hyphae confirmed cases of septic embolus ${ }^{137}$ and angioinvasive mucormycosis secondary to sinusitis. ${ }^{138}$ Identification of papillary fronds or myxomatous tissue helped diagnose embolization secondary to cardiac papillary fibroelastoma ${ }^{15,16,20}$ and myxo$\mathrm{ma}_{1}{ }^{29}$ respectively. Visual assessment and histopathology identified valve tissue ${ }_{1}^{24}$ calcifications, ${ }_{1}^{27,30}$ chordae tendineae ${ }_{1}{ }^{21}$ and aortic wall tissue ${ }^{23}$ as embolism sources, which detached spontaneously or periprocedurally during valve replacement surgery. Immunohistopathology contributed to diagnose the embolism of a Libman-Sacks vegetation in systemic lupus erythematosus-associated endocarditis. ${ }^{22}$ Thrombus calcification, cholesterol crystal cleft and foamy cells confirmed the aortogenic embolic stroke due to atheromatous lesion in the aortic arch. ${ }^{139,140}$ Embolizations of carotid free-floating and carotid web thrombi were determined by assessing the clot aspect and blood cell content. ${ }^{28,141}$ Clot visual appearance and high FBR content indicated thromboembolism secondary to coronavirus disease 2019-associated hypercoagulability ${ }^{34}$ and cancer-related Trousseau syndrome. ${ }^{33}$ Finally, thrombus examination confirmed periprocedural catheter-related thromboembolism during valve implantation ${ }^{17}$ and inadvertent embolization of foreign bodies during aneurysm treatment. ${ }^{25}$

\section{Discussion}

In response to the four research questions posed in this study, our results show that:

(1) Thrombi were subjected to physical analyses (macroscop- ic appearance, mechanical behavior, MRI, and synchrotron-based imaging), histopathological analyses (conventional histology, immunohistochemistry, and electron microscopy), biological analyses (biochemical, biomolecular, and cellular techniques, such as enzymatic assay, ELISA, transcriptomics, proteomics, metabolomics, and flow cytometry), and microbiological analyses (culture, histological staining, and metagenomics).

(2) The information obtained about thrombi included gross appearance (size, shape, consistency, visual texture, color, and homo/heterogeneous aspect), mechanical properties (stiffness, elasticity, tensile strength, and response to stress), structure (compactness, molecular and cellular organization, and ultrastructure), and composition (FBR, other coagulation factors, blood formed elements, NETs, vessel wall and plaque components, microbial pathogens, inflammatory mediators, protein cargo, metabolites, elements, and even foreign bodies).

(3) There were associations of thrombus size, structure and composition (mainly proportions of FBR and blood formed elements) with TOAST etiology and underlying pathologies, and similarities between cryptogenic thrombi and those of known TOAST etiology.

(4) Individual thrombus analysis proved to be a valuable complementary tool in the diagnosis of stroke etiology, particularly in atypical cases.

The first endovascular device clearance by the U.S. Food and Drug Administration occurred in 2004, ${ }^{148}$ and the first report describing a systematic histological analysis of thrombi retrieved from cerebral arteries was published in 2006. ${ }^{7}$ Since then, a total of 134 eligible studies have been identified in this systematic review. Of note, there has been a surge of reports in the last 5 years, just after the publication of Brinjikji's systematic review. ${ }^{3}$ Although most studies carried out histopathological analyses, studies reporting biochemical or biomolecular analyses have been increasing in the last 3 years. Almost 10,000 thrombi/emboli retrieved from LVO stroke patients have been analyzed predominantly in cohort studies but also in case reports.

Physical, histopathological and biological analyses provided a considerable amount of information about the gross appearance, mechanical properties, structure, and composition of thrombi in patient cohorts. However, assessments of possible associations of thrombus features with stroke causes have been carried out mainly based on thrombus size, color, and proportions of FBR and blood formed elements. LAA thrombi were larger and more fragmented. Regarding composition, non-unanimous evidence supported higher RBC contents in 
thrombi from LAA or non-CE (LAA+ODC) sources, and higher FBR contents in thrombi of CE origin. WBC content, neutrophil count, and NETosis were also higher in CE thrombi. As for the PLT proportion, controversial histopathological evidence did not support a clear association with the CE or non-CE cause, although non-CE thrombi showed higher GP VI content (PLT marker), and peripheral PDP. Cryptogenic mechanisms account for $10 \%$ to $40 \%$ of all ischemic strokes. ${ }^{149}$ Most evidence pointed to similar features in CRY and CE thrombi, mainly regarding proportions of RBCs, FBR, PLTs, and WBCs, and smaller size and number of retrieved fragments, clustering PDP, and higher NETosis. This could aid the etiologic investigation and reduce the percentage of CRY strokes. Of note, the large multicentric STRIP registry found statistically significant but clinically insignificant differences between clots of CE and LAA etiologies. ${ }^{147}$ Although LAA clots had a higher mean RBC density and a lower mean PLT density than CE clots, the receiver operating characteristics analysis showed that identification of a reliable threshold with a high area under the curve for differentiating clots of these two etiologies based on composition analysis alone was not possible; this suggests that conventional histological analyses of the cellular composition do not provide insights into stroke etiology in cryptogenic cases. Regardless of TOAST etiology, a few studies found associations of thrombus color and composition with underlying pathologies like cancer, diabetes, and IE.

Macroscopic, histopathological, biomolecular, and microbiological analyses of thrombi were useful in the diagnosis of the stroke cause in individual cases. Thrombus features confirmed cases of typical intracranial and carotid thromboembolism, and atypical free-floating and web thrombi. Histopathology also contributed to diagnose embolisms due to cardiac tumor fragments, sterile endocarditis vegetations, aortogenic lesions, and tissue fragments detached during valve replacement surgery. Microbiological analysis revealed septic emboli secondary to IE, allowing appropriate antibiotic therapy. Finally, thromboembolisms due to secondary hypercoagulable states were diagnosed based on clot features.

Current methods of assessing thrombus features vary widely. Despite a consensus statement on the analyses of thrombi in AIS $^{1}$ and recommendations for thrombus handling and procedures, ${ }^{13}$ the results in this review show a lack of standardization in the research and reporting of thrombus characteristics and parameters. Heterogeneity in study designs, outcome measuring, and reporting precluded a meta-analysis of the association between thrombus composition and stroke etiology. Hopefully, ongoing multi-institutional registers, larger cohorts, and homogenous protocols will overcome this limitation. Although traditional histopathological techniques seem of limited value, the application of pathophysiological classifications show promise in differentiating between CE and LAA emboli. ${ }^{150} \mathrm{Nev}$ ertheless, focusing on immunohistochemical analysis and more advanced techniques could help increase the knowledge on the composition and structure of thrombi. Advanced analysis of microRNA signatures, ${ }^{151}$ proteomic analysis, ${ }^{152}$ and combined "omic" analysis (proteome and metabolome) ${ }^{153}$ are promising molecular approaches to elucidate the composition of emboli. Moreover, ultrastructural analysis using high-resolution SEM shows the finely organized clot components..$^{56}$ The role of all these advanced techniques in identifying stroke etiology could be further explored.

\section{Conclusions}

Although cohort studies report an abundance of quantitative rates of main thrombus components, a definite clot signature for accurate diagnosis of stroke etiology is still lacking. Nevertheless, qualitative examination of the embolus remains an invaluable tool in the diagnostic work-up of individual cases, particularly regarding atypical stroke causes. Beyond conventional histopathological and immunohistochemical clot analyses, future studies should emphasize the analysis of biomolecular composition and structural organization to provide insights about reliable links between clot features and stroke etiology.

\section{Supplementary materials}

Supplementary materials related to this article can be found online at https://doi.org/10.5853/jos.2021.02306.

\section{Disclosure}

The authors have no financial conflicts of interest.

\section{Acknowledgments}

This work was partially supported by RETICS research network INVICTUS+ from Spanish 'Instituto de Salud Carlos III' (co-financed with European Regional Development Fund), through grant RD16/0019/0008. The funding source had no further role in study design; in the collection, analysis, and interpretation of data; in the writing of the report; and in the decision to submit the paper for publication.

The authors acknowledge the help rendered by Marta Méndez Debaets in manuscript preparation and reference management. 


\section{References}

1. De Meyer SF, Andersson T, Baxter B, Bendszus M, Brouwer $P$, Brinjikji $W$, et al. Analyses of thrombi in acute ischemic stroke: a consensus statement on current knowledge and future directions. Int J Stroke 2017;12:606-614.

2. Bacigaluppi M, Semerano A, Gullotta GS, Strambo D. Insights from thrombi retrieved in stroke due to large vessel occlusion. J Cereb Blood Flow Metab 2019;39:1433-1451.

3. Brinjikji W, Duffy $S$, Burrows $A$, Hacke W, Liebeskind D, Majoie $C B$, et al. Correlation of imaging and histopathology of thrombi in acute ischemic stroke with etiology and outcome: a systematic review. J Neurointerv Surg 2017;9:529-534.

4. Jolugbo P, Ariëns RA. Thrombus composition and efficacy of thrombolysis and thrombectomy in acute ischemic stroke. Stroke 2021;52:1131-1142.

5. Liberati A, Altman DG, Tetzlaff J, Mulrow C, Gøtzsche PC, loannidis JP, et al. The PRISMA statement for reporting systematic reviews and meta-analyses of studies that evaluate health care interventions: explanation and elaboration. PLoS Med 2009;6:e1000100.

6. Salom JB, Aliena-Valero A, Torregrosa G, Baixauli-Martín J. Clot composition analysis as complementary diagnostic tool to gain insight into ischemic stroke etiology: A systematic review of clinical studies and case reports. National Institute for Health Reearch. https://www.crd.york.ac.uk/prospero/display_ record.php?|D=CRD42020199436. August 17, 2020. Accessed September 27, 2021.

7. Marder VJ, Chute DJ, Starkman S, Abolian AM, Kidwell C, Liebeskind $D$, et al. Analysis of thrombi retrieved from cerebral arteries of patients with acute ischemic stroke. Stroke 2006; 37:2086-93.

8. Multimodal Investigation of Intracranial Clot Environment (MISO). ClinicalTrials.gov. https://clinicaltrials.gov/ct2/show/ NCT04421326. 2020. Accessed September 27, 2021.

9. Investigation of Clot in Ischemic Stroke and Hematoma Evacuation (INSIGHT). ClinicalTrials.gov. https://clinicaltrials.gov/ ct2/show/NCT04693767. 2021. Accessed September 27, 2021.

10. Thrombus Composition in Ischemic Stroke: Analysis of the Correlation With Plasma Biomarkers, Efficacy of Treatment, Etiology and Prognosis (COMPO-CLOT). ClinicalTrials.gov. https://clinicaltrials.gov/ct2/show/NCT03268668. 2021. Accessed September 27, 2021.

11. Blood And Clot Thrombectomy Registry And Collaboration (BACTRAC). ClinicalTrials.gov. https://clinicaltrials.gov/ct2/ show/NCT03153683. 2021. Accessed September 27, 2021.

12. RNA Sequencing Analysis in Large Vessel Occlusion Stroke DATA Bank (RNASA-LVOSB). ClinicalTrials.gov. https://clinical-
trials.gov/ct2/show/NCT03490552. 2018. Accessed September 27, 2021.

13. Staessens $S$, Fitzgerald $S$, Andersson $T$, Clarençon F, Denorme F, Gounis MJ, et al. Histological stroke clot analysis after thrombectomy: technical aspects and recommendations. Int J Stroke 2020;15:467-476.

14. Abdel-Wahed L, Shaban A, Hayakawa M, Limaye K. Retrieved arterial clot helps guide antibiotic therapy in infective endocarditis. Am J Med 2019;132:e795-e796.

15. Biraschi F, Diana F, Alesini F, Guidetti G, Peschillo S. Effective ADAPT thrombectomy in a patient with acute stroke due to cardiac papillary elastofibroma: histological thrombus confirmation. J Stroke Cerebrovasc Dis 2016;25:e185-e187.

16. Salam KA, Rafeeque M, Hashim H, Mampilly $N$, Noone ML. Histology of thrombectomy specimen reveals cardiac tumor embolus in cryptogenic young stroke. J Stroke Cerebrovasc Dis 2018;27:e70-e72.

17. Salinas P, Moreno R, Frutos R, Lopez-Sendon JL. Neurovascular rescue for thrombus-related embolic stroke during transcatheter aortic valve implantation. JACC Cardiovasc Interv 2013;6:981-982.

18. Scharf EL, Chakraborty T, Rabinstein A, Miranpuri AS. Endovascular management of cerebral septic embolism: three recent cases and review of the literature. J Neurointerv Surg 2017;9:463-465.

19. Semerano A, Genchi A, Callea M, Sanvito F, Simionato F, Panni $P$, et al. Thrombus hallmarks reveal atherothrombotic stroke aetiology. J Neurol 2019;266:1533-1535.

20. Tejada J, Galiana A, Balboa O, Clavera B, Redondo-Robles L,

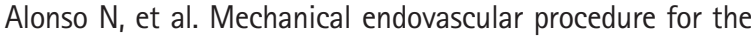
treatment of acute ischemic stroke caused by total detachment of a papillary fibroelastoma. J Neurointerv Surg 2014; 6:e37.

21. Thomas MC, Delgado Almandoz JE, Todd AJ, Young ML, Fease $J \mathrm{~L}$, Scholz JM, et al. A case of right middle cerebral artery 'tendonectomy' following mitral valve replacement surgery. J Neurointerv Surg 2017;9:e35.

22. Valente M, Saab J, Cordato D, Manning N, Cappelen-Smith C. The diagnostic utility of routine clot analysis after endovascular thrombectomy in a patient with systemic lupus erythematosus and antiphospholipid syndrome. J Clin Neurosci 2019; 70:247-249.

23. Wollenweber FA, Remi J, Bauer A, Theiss $H$, Massberg $S$, Patzig $M$, et al. Thrombectomy recovers an aortic wall fragment from middle cerebral artery immediately after TAVI. Neurology 2016;86:2111-2112.

24. Anuwatworn A, Raizada A, Kelly S, Stys $T$, Jonsson O, Stys A. Stroke with valve tissue embolization during transcatheter 
aortic valve replacement treated with endovascular intervention. JACC Cardiovasc Interv 2015;8:1261-1263.

25. Chapot R, Wassef M, Bisdorff A, Rogopoulos A, Merland JJ, Houdart E. Occlusion of the middle cerebral artery due to synthetic fibers. AJNR Am J Neuroradiol 2006;27:148-150.

26. Elodie O, Labeyrie PE, Aubry M, Cecile D, Roux S, Ferry T, et al. Whipple's endocarditis diagnosed by thrombus analysis retrieved by successful mechanical thrombectomy. J Neurol Sci 2019;400:42-43.

27. Fassa $A A$, Mazighi $M$, Himbert $D$, Deschamps $L$, Ducrocq $G$, Cheong $A P$, et al. Successful endovascular stroke rescue with retrieval of an embolized calcium fragment after transcatheter aortic valve replacement. Circ Cardiovasc Interv 2014;7:125126.

28. Fitzpatrick N, Motyer R, Gibney B, Duffy S, Murphy S, O'Brien $P$, et al. Expanding the role of stent-retriever endovascular thrombectomy: a case series of free-floating thrombus. $J$ Neurointerv Surg 2018;10:1164-1167.

29. Garcia-Ptacek S, Matias-Guiu JA, Valencia-Sánchez C, Gil A,

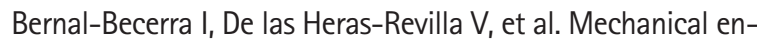
dovascular treatment of acute stroke due to cardiac myxoma. J Neurointerv Surg 2014;6:e1.

30. Genchi A, Schwarz G, Semerano A, Callea M, Sanvito F, Simionato $F$, et al. Large vessel occlusion stroke due to dislodged aortic valve calcification revealed by imaging and histopathology. J Neurol Sci 2020;408:116573.

31. Kan P, Webb S, Siddiqui AH, Levy El. First reported use of retrievable stent technology for removal of a large septic embolus in the middle cerebral artery. World Neurosurg 2012; 77:591.

32. Kim JM, Jeon JS, Kim YW, Kang DH, Hwang YH, Kim YS. Forced arterial suction thrombectomy of septic embolic middle cerebral artery occlusion due to infective endocarditis: an illustrative case and review of the literature. Neurointervention 2014;9:101-5.

33. Matsumoto $N$, Fukuda $H$, Handa $A$, Kawasaki $T$, Kurosaki $Y_{1}$ Chin $M$, et al. Histological examination of trousseau syndrome-related thrombus retrieved through acute endovascular thrombectomy: report of 2 cases. J Stroke Cerebrovasc Dis 2016;25:e227-e230.

34. Pisano TJ, Hakkinen I, Rybinnik I. Large vessel occlusion secondary to COVID-19 hypercoagulability in a young patient: a case report and literature review. J Stroke Cerebrovasc Dis 2020;29:105307.

35. Bourcier R, Duchmann Z, Sgreccia A, Desal H, Carità G, Desilles JP, et al. Diagnostic performances of the susceptibility vessel sign on MRI for the prediction of macroscopic thrombi features in acute ischemic stroke. J Stroke Cerebrovasc Dis
2020;29:105245.

36. Sgreccia A, Duchmann Z, Desilles JP, Lapergue B, Labreuche J, Kyheng $M$, et al. Association between acute ischemic stroke etiology and macroscopic aspect of retrieved clots: is a clot's color a warning light for underlying pathologies? J Neurointerv Surg 2019;11:1197-1200.

37. Choi MH, Park GH, Lee JS, Lee SE, Lee SJ, Kim JH, et al. Erythrocyte fraction within retrieved thrombi contributes to thrombolytic response in acute ischemic stroke. Stroke 2018; 49:652-659.

38. Fu CH, Chen $\mathrm{CH}$, Lin YH, Lee CW, Tsai LK, Tang SC, et al. Fibrin and platelet-rich composition in retrieved thrombi hallmarks stroke with active cancer. Stroke 2020;51:3723-3727.

39. Fitzgerald $S$, Rossi R, Mereuta OM, Jabrah D, Okolo A, Douglas $A$, et al. Per-pass analysis of acute ischemic stroke clots: impact of stroke etiology on extracted clot area and histological composition. J Neurointerv Surg 2020 Dec 9 [Epub]. https:// doi.org/10.1136/neurintsurg-2020-016966.

40. Fitzgerald S, Rossi R, Mereuta OM, Molina S, Okolo A, Douglas $A$, et al. Large artery atherosclerotic clots are larger than clots of other stroke etiologies and have poorer recanalization rates. J Stroke Cerebrovasc Dis 2021;30:105463.

41. Rossi R, Fitzgerald S, Molina S, Mereuta OM, Douglas A, Pandit $A$, et al. The administration of rtPA before mechanical thrombectomy in acute ischemic stroke patients is associated with a significant reduction of the retrieved clot area but it does not influence revascularization outcome. J Thromb Thrombolysis 2021;51:545-551.

42. Horie N, Shobayashi K, Morofuji Y, Sadakata E, Iki Y, Matsunaga $Y$, et al. Impact of mechanical thrombectomy device on thrombus histology in acute embolic stroke. World Neurosurg 2019;132:e418-e422.

43. Almekhlafi MA, Hu WY, Hill MD, Auer RN. Calcification and endothelialization of thrombi in acute stroke. Ann Neurol 2008;64:344-348.

44. Chueh JY, Wakhloo AK, Hendricks GH, Silva CF, Weaver JP, Gounis MJ. Mechanical characterization of thromboemboli in acute ischemic stroke and laboratory embolus analogs. AJNR Am J Neuroradiol 2011;32:1237-1244.

45. Liu Y, Zheng Y, Reddy AS, Gebrezgiabhier D, Davis E, Cockrum $J$, et al. Analysis of human emboli and thrombectomy forces in large-vessel occlusion stroke. J Neurosurg 2020;134:893-901.

46. Vidmar J, Bajd F, Milosevic ZV, Kocijancic IJ, Jeromel M, Sersa I. Retrieved cerebral thrombi studied by $\mathrm{T} 2$ and $\mathrm{ADC}$ mapping: preliminary results. Radiol Oncol 2019;53:427-433.

47. Meher V, Pushie J, Sylvain N, Weese Maley S, Hou H, Peeling $L$, et al. Analysis of retrieved stroke thrombi from mechanical thrombectomy using $\mathrm{X}$-ray fluorescence imaging and fourier- 
transform infrared spectroscopy. Int J Stroke 2018;13:150.

48. Fitzgerald S, Wang S, Dai D, Murphree DH Jr, Pandit A, Douglas $A$, et al. Orbit image analysis machine learning software can be used for the histological quantification of acute ischemic stroke blood clots. PLoS One 2019;14:e0225841.

49. Fitzgerald ST, Wang S, Dai D, Douglas A, Kadirvel R, Gounis $\mathrm{MJ}$, et al. Platelet-rich clots as identified by Martius Scarlet Blue staining are isodense on NCCT. J Neurointerv Surg 2019; 11:1145-1149.

50. Fitzgerald S, Dai D, Wang S, Douglas A, Kadirvel R, Layton KF, et al. Platelet-rich emboli in cerebral large vessel occlusion are associated with a large artery atherosclerosis source. Stroke 2019;50:1907-1910.

51. Kim B, Kim YM, Jin SC, Lee JW, Lee BI, Kim SE, et al. Development of a predictive scale for cardioembolic stroke using extracted thrombi and angiographic findings. J Clin Neurosci 2020;73:224-230.

52. Schuhmann MK, Gunreben I, Kleinschnitz C, Kraft P. Immunohistochemical analysis of cerebral thrombi retrieved by mechanical thrombectomy from patients with acute ischemic stroke. Int J Mol Sci 2016;17:298.

53. Staessens S, Denorme F, Francois O, Desender L, Dewaele T, Vanacker $P$, et al. Structural analysis of ischemic stroke thrombi: histological indications for therapy resistance. Haematologica 2020;105:498-507.

54. Ye G, Qi P, Chen K, Tan T, Cao R, Chen J, et al. Risk of secondary embolism events during mechanical thrombectomy for acute ischemic stroke: a single-center study based on histological analysis. Clin Neurol Neurosurg 2020;193:105749.

55. Ye G, Gao Q, Qi P, Wang J, Hu S, Chen K, et al. The role of diabetes mellitus on the thrombus composition in patients with acute ischemic stroke. Interv Neuroradiol 2020;26:329-336.

56. Mereuta OM, Fitzgerald $\mathrm{S}$, Christensen $T A$, Jaspersen $A L$, Dai $D$, Abbasi $M$, et al. High-resolution scanning electron microscopy for the analysis of three-dimensional ultrastructure of clots in acute ischemic stroke. J Neurointerv Surg 2021;13: 906-911.

57. Ahn SH, Hong R, Choo IS, Heo JH, Nam HS, Kang HG, et al. Histologic features of acute thrombi retrieved from stroke patients during mechanical reperfusion therapy. Int J Stroke 2016;11:1036-1044.

58. Benson JC, Fitzgerald ST, Kadivel R, Johnson C, Dai D, Karen $D$, et al. Clot permeability and histopathology: is a clot's perviousness on CT imaging correlated with its histologic composition? J Neurointerv Surg 2020;12:38-42.

59. Brinjikji W, Fitzgerald S, Kallmes DF, Layton K, Hanel R, Pereira $\mathrm{VM}$, et al. Outcomes of the stroke thromboembolism registry of imaging and pathology: a multicenter international study.
Stroke 2020;51(Suppl 1):A147.

60. Douglas A, Fitzgerald S, Mereuta OM, Rossi R, O'Leary S, Pan$\operatorname{dit} A$, et al. Platelet-rich emboli are associated with von Willebrand factor levels and have poorer revascularization outcomes. J Neurointerv Surg 2020;12:557-562.

61. Duffy $S$, McCarthy $R$, Farrell M, Thomas S, Brennan P, Power $\mathrm{S}$, et al. Per-pass analysis of thrombus composition in patients with acute ischemic stroke undergoing mechanical thrombectomy. Stroke 2019;50:1156-1163.

62. Khismatullin RR, Shakirova AZ, Weisel JW, Litvinov RI. Agedependent differential staining of fibrin in blood clots and thrombi. BioNanoScience 2020;10:370-374.

63. Di Meglio L, Desilles JP, Ollivier V, Nomenjanahary MS, Di Meglio S, Deschildre C, et al. Acute ischemic stroke thrombi have an outer shell that impairs fibrinolysis. Neurology 2019;93:e1686-e1698.

64. Niesten JM, van der Schaaf IC, van Dam L, Vink A, Vos JA, Schonewille WJ, et al. Histopathologic composition of cerebral thrombi of acute stroke patients is correlated with stroke subtype and thrombus attenuation. PLoS One 2014;9:e88882.

65. Park H, Kim J, Ha J, Hwang IG, Song TJ, Yoo J, et al. Histological features of intracranial thrombi in stroke patients with cancer. Ann Neurol 2019;86:143-149.

66. Novotny J, Oberdieck P, Titova A, Pelisek J, Chandraratne S, Nicol $P$, et al. Thrombus NET content is associated with clinical outcome in stroke and myocardial infarction. Neurology 2020;94:e2346-e2360.

67. Goebel J, Gaida BJ, Wanke I, Kleinschnitz C, Koehrmann M, Forsting $\mathrm{M}$, et al. Is histologic thrombus composition in acute stroke linked to stroke etiology or to interventional parameters? AJNR Am J Neuroradiol 2020;41:650-657.

68. Sporns PB, Krähling $H$, Psychogios MN, Jeibmann A, Minnerup J, Broocks G, et al. Small thrombus size, thrombus composition, and poor collaterals predict pre-interventional thrombus migration. J Neurointerv Surg 2021;13:409-414.

69. Sporns PB, Jeibmann A, Minnerup J, Broocks G, Nawabi J, Schön $\mathrm{G}$, et al. Histological clot composition is associated with preinterventional clot migration in acute stroke patients. Stroke 2019;50:2065-2071.

70. Sporns PB, Hanning U, Schwindt W, Velasco A, Buerke B, Cny-

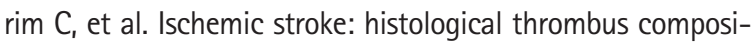
tion and pre-interventional CT attenuation are associated with intervention time and rate of secondary embolism. Cerebrovasc Dis 2017;44:344-350.

71. Peña-Martínez $C$, Durán-Laforet $V$, García-Culebras $A$, Ostos $F$, Hernández-Jiménez $M$, Bravo-Ferrer I, et al. Pharmacological modulation of neutrophil extracellular traps reverses thrombotic stroke tPA (tissue-type plasminogen activator) re- 
sistance. Stroke 2019;50:3228-3237.

72. Kim SK, Yoon W, Kim TS, Kim HS, Heo TW, Park MS. Histologic analysis of retrieved clots in acute ischemic stroke: correlation with stroke etiology and gradient-echo MRI. AJNR Am J Neuroradiol 2015;36:1756-1762.

73. Nouh A, Mehta $T$, Hussain M, Song $X$, Ollenschleger M. Clot composition of embolic strokes of undetermined source: a feasibility study. BMC Neurol 2020;20:383.

74. López-Cancio $E_{1}$ Millán $M$, Pérez de la Ossa N, Dávalos A, Ribó $M$, Morancho $A$, et al. Immunohistochemical study of clot composition in thrombi retrieved from MCA with mechanical thrombectomy. Cerebrovasc Dis 2013;35:255.

75. Elijovich L, Arthur A, Hoit D, Nickele C, Morris D, Vachhani J, et al. Thrombus composition is associated with endothelial injury and stroke etiology in patients undergoing mechanical thrombectomy for emergent large vessel occlusion. Stroke 2018;49(Suppl 1):A145.

76. Essig F, Kollikowski AM, Pham M, Solymosi L, Stoll G, Haeusler $K G$, et al. Immunohistological analysis of neutrophils and neutrophil extracellular traps in human thrombemboli causing acute ischemic stroke. Int J Mol Sci 2020;21:7387.

77. Gurkas E, Asif A, Akpinar CK, Shoukat M, Aytac E, Aydin MC, et al. Thrombus composition and success of thrombectomy in acute ischemic stroke patients: a histopathological analysis. Stroke 2019;50(Suppl 1):AWP36.

78. Hashimoto T, Hayakawa M, Funatsu N, Yamagami H, Satow T, Takahashi JC, et al. Histopathologic analysis of retrieved thrombi associated with successful reperfusion after acute stroke thrombectomy. Stroke 2016;47:3035-3037.

79. Liebeskind DS, Sanossian N, Yong WH, Starkman S, Tsang MP, Moya $A L$, et al. $C T$ and $M R I$ early vessel signs reflect clot composition in acute stroke. Stroke 2011;42:1237-1243.

80. Liu M, Hao Z, Li R, Cai J, Jiang C, Li Y. Erythrocyte-rich thrombi related to serum iron contribute to single stent retrieval and favorable clinical outcomes in acute ischemic stroke by endovascular treatment. Thromb Res 2020;195:8-15.

81. Maegerlein C, Friedrich $B$, Berndt M, Lucia KE, Schirmer $L$,

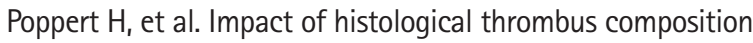
on preinterventional thrombus migration in patients with acute occlusions of the middle cerebral artery. Interv Neuroradiol 2018;24:70-75.

82. Maekawa $K$, Shibata M, Nakajima H, Mizutani A, Kitano $Y$, Seguchi $M$, et al. Erythrocyte-rich thrombus is associated with reduced number of maneuvers and procedure time in patients with acute ischemic stroke undergoing mechanical thrombectomy. Cerebrovasc Dis Extra 2018;8:39-49.

83. Qureshi Al, Qureshi MH, Lobanova I, Bashir A, Khan AA, Bologna SM, et al. Histopathological characteristics of IV recom- binant tissue plasminogen-resistant thrombi in patients with acute ischemic stroke. J Vasc Interv Neurol 2016;8:38-45.

84. Shin JW, Jeong HS, Kwon HJ, Song KS, Kim J. High red blood cell composition in clots is associated with successful recanalization during intra-arterial thrombectomy. PLoS One 2018; 13:e0197492.

85. Simons N, Mitchell P, Dowling R, Gonzales M, Yan B. Thrombus composition in acute ischemic stroke: a histopathological study of thrombus extracted by endovascular retrieval. J Neuroradiol 2015;42:86-92.

86. Singh $\mathrm{P}$, Doostkam $\mathrm{S}$, Reinhard $\mathrm{M}$, Ivanovas $\mathrm{V}$, Taschner CA. Immunohistochemical analysis of thrombi retrieved during treatment of acute ischemic stroke: does stent-retriever cause intimal damage? Stroke 2013;44:1720-1722.

87. Darcourt J, Garcia C, Phuong DM, Michelozzi C, Bellanger G, Adam $G$, et al. Absence of susceptibility vessel sign is associated with aspiration-resistant fibrin/platelet-rich thrombi. Int J Stroke 2021 Jan 12 [Epub]. https://doi.org/10.1177/1747493020986626.

88. Hanning U, Sporns PB, Psychogios MN, Jeibmann A, Minnerup $J$, Gelderblom $M$, et al. Imaging-based prediction of histological clot composition from admission CT imaging. J Neurointerv Surg 2021 Jan 22 [Epub]. https://doi.org/10.1136/neurintsurg-2020-016774.

89. Boeckh-Behrens T, Schubert M, Förschler A, Prothmann S,

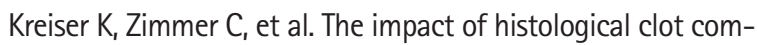
position in embolic stroke. Clin Neuroradiol 2016;26:189-197.

90. Dargazanli C, Rigau V, Eker O, Riquelme Bareiro C, Machi P, Gascou G, et al. High CD3+ cells in intracranial thrombi represent a biomarker of atherothrombotic stroke. PLoS One 2016;11:e0154945.

91. Donnerstag F, Götz F, Dadak M, Raab P, Iglesias EC, Werlein C, et al. Interventional stroke treatment: is it also safe for arteries?: looking at thrombectomy wall damage through clot histology. Interv Neuroradiol 2021;27:404-410.

92. Kaesmacher J, Boeckh-Behrens T, Simon S, Maegerlein C, Kleine JF, Zimmer $\mathrm{C}$, et al. Risk of thrombus fragmentation during endovascular stroke treatment. AJNR Am J Neuroradiol 2017;38:991-998.

93. Laridan $E$, Denorme $F$, Desender $L$, François O, Andersson $T$, Deckmyn $\mathrm{H}_{\text {, et }}$ al. Neutrophil extracellular traps in ischemic stroke thrombi. Ann Neurol 2017;82:223-232.

94. Deng J, Zhao F, Zhang Y, Zhou Y, Xu X, Zhang $X$, et al. Neutrophil extracellular traps increased by hyperglycemia exacerbate ischemic brain damage. Neurosci Lett 2020;738:135383.

95. Ducroux C, Di Meglio L, Loyau S, Delbosc S, Boisseau W, Deschildre $C_{\text {, et }}$ al. Thrombus neutrophil extracellular traps content impair tPA-induced thrombolysis in acute ischemic stroke. Stroke 2018;49:754-757. 
96. Sporns PB, Hanning U, Schwindt W, Velasco A, Minnerup J, Zoubi $T$, et al. Ischemic stroke: what does the histological composition tell us about the origin of the thrombus? Stroke 2017;48:2206-2210.

97. Prochazka V, Jonszta T, Czerny D, Krajca J, Roubec M, Macak J, et al. The role of von Willebrand factor, ADAMTS13, and cerebral artery thrombus composition in patient outcome following mechanical thrombectomy for acute ischemic stroke. Med Sci Monit 2018;24:3929-3945.

98. Krajičková D, Krajina A, Šteiner I, Vyšata O, Herzig R, Lojík M, et al. Fibrin clot architecture in acute ischemic stroke treated with mechanical thrombectomy with stent-retrievers: cohort study. Circ J 2018;82:866-873.

99. Chen SH, Scott XO, Ferrer Marcelo Y, Almeida VW, Blackwelder PL, Yavagal DR, et al. Netosis and inflammasomes in large vessel occlusion thrombi. Front Pharmacol 2021;11:607287.

100. Mereuta OM, Fitzgerald S, Abbasi M, Dai D, Kadirvel $R$, Kallmes DF, et al. Von Willebrand factor expression in various subtypes of acute ischemic stroke. Stroke 2020;51(Suppl 1):AWP268.

101. Funatsu $N$, Hayakawa $M$, Hashimoto $T$, Yamagami $H$, Satow $T$, Takahashi JC, et al. Vascular wall components in thrombi obtained by acute stroke thrombectomy: clinical significance and related factors. J Neurointerv Surg 2019;11:232-236.

102. Bhaskar S, Saab J, Cappelen-Smith C, Killingsworth M, Wu XJ, Cheung $A$, et al. Clot histopathology in ischemic stroke with infective endocarditis. Can J Neurol Sci 2019;46:331-336.

103. Mehta RI, Rai AT, Vos JA, Solis OE, Mehta RI. Intrathrombus polymer coating deposition: a pilot study of 91 patients undergoing endovascular therapy for acute large vessel stroke. Part I: Histologic frequency. J Neurointerv Surg 2019;11:11911196.

104. Hund HM, Taha A, Ramlal SA, Hansen D, Autar ASA, van de Lugt $A$, et al. Foreign bodies are present in thrombi mechanically extracted from patients suffering acute ischemic stroke and who underwent endovascular treatment. J Cereb Blood Flow Metab 2019;39:261.

105. Sallustio F, Arnò N, Di Legge $S$, Koch G, Martorana A, Rossi C, et al. Histological features of intracranial thrombo-emboli predict response to endovascular therapy for acute ischemic stroke. J Neurol Disord Stroke 2015;3:1105.

106. Cline B, Vos J, Carpenter J, Rai A. Pathological analysis of extracted clots in embolectomy patients with acute ischaemic stroke. J Neurolnterv Surg 2013;5(Suppl 2):A15-A16.

107. Li Y, Wang H, Zhao L, Jian Y, Dang M, Jiang Y, et al. A case report of thrombolysis resistance: thrombus ultrastructure in an ischemic stroke patient. BMC Neurol 2020;20:135.

108. Khashim Z, Fitzgerald S, Kadirvel R, Dai D, Doyle KM, Brinjikji
W, et al. Clots retrieved by mechanical thrombectomy from acute ischemic stroke patients show no evidence of bacteria. Interv Neuroradiol 2019;25:502-507.

109. Hernández-Fernández $F$, Rojas-Bartolomé L, García-García J, Ayo-Martín Ó, Molina-Nuevo JD, Barbella-Aponte RA, et al. Histopathological and bacteriological analysis of thrombus material extracted during mechanical thrombectomy in acute stroke patients. Cardiovasc Intervent Radiol 2017;40:18511860.

110. Patrakka O, Pienimäki JP, Tuomisto $S$, Ollikainen J, Lehtimäki T, Karhunen PJ, et al. Oral bacterial signatures in cerebral thrombi of patients with acute ischemic stroke treated with thrombectomy. J Am Heart Assoc 2019;8:e012330.

111. Vajpeyee A, Chauhan PS, Pandey S, Tiwari S, Yadav LB, Shroti $A K$, et al. Metagenomics analysis of thrombus samples retrieved from mechanical thrombectomy. Neurointervention 2021;16:39-45.

112. Baek BH, Kim HS, Yoon W, Lee YY, Baek JM, Kim EH, et al. Inflammatory mediator expression within retrieved clots in acute ischemic stroke. Ann Clin Transl Neurol 2018;5:273-279.

113. Rao NM, Capri J, Cohn W, Abdaljaleel M, Restrepo L, Gornbein $J A$, et al. Peptide composition of stroke causing emboli correlate with serum markers of atherosclerosis and inflammation. Front Neurol 2017;8:427.

114. Muñoz R, Santamaría E, Rubio I, Ausín $K_{1}$ Ostolaza A, Labarga $A$, et al. Mass spectrometry-based proteomic profiling of thrombotic material obtained by endovascular thrombectomy in patients with ischemic stroke. Int J Mol Sci 2018;19:498.

115. Dargazanli C, Zub E, Deverdun J, Decourcelle M, de Bock F, Labreuche J, et al. Machine learning analysis of the cerebrovascular thrombi proteome in human ischemic stroke: an exploratory study. Front Neurol 2020;11:575376.

116. Lopez-Pedrera C, Ibañez-Costa A, Perez-Sanchez C, LuqueTevar M, Patiño-Trives AM, Abalos-Aguilera MDC, et al. Characterization of the protein profile in thrombi of patients with ischemic stroke and identification of potential biomarkers as predictors of negative clinical evolution. Res Pract Thromb Haemost 2020;4(Suppl 1):0C08.5.

117. Suissa L, Guigonis JM, Graslin F, Doche E, Osman O, Chau Y, et al. Metabolome of cerebral thrombi reveals an association between high glycemia at stroke onset and good clinical outcome. Metabolites 2020;10:483.

118. Di Meglio L, Desilles JP, Solonomenjanahary M, Labreuche J, Ollivier $\mathrm{V}$, Dupont $\mathrm{S}$, et al. DNA content in ischemic stroke thrombi can help identify cardioembolic strokes among strokes of undetermined cause. Stroke 2020;51:2810-2816.

119. Di Meglio L, Derraz I, Solonomenjanahary M, Daly D, Chodraui Filho S, Ben Maacha M, et al. Two-layered susceptibility ves- 
sel sign is associated with biochemically quantified thrombus red blood cell content. Eur J Neurol 2020;27:1264-1271.

120. Juega J, Pagola J, Palacio C, Camacho J, Cardona P, Quesada $\mathrm{H}$, et al. Etiology of stroke based on early analysis of clot cytometry obtained through first pass technique for mechanical thrombectomy. Stroke 2019;50(Suppl 1):AWMP70.

121. Itsekson Hayosh Z, Abu Bandora E, Shelestovich N, Nulman M, Bakon M, Yaniv G, et al. In-thrombus thrombin secretion: a new diagnostic marker of atrial fibrillation in cryptogenic stroke. J Neurointerv Surg 2021;13:799-804.

122. Boeckh-Behrens T, Kleine JF, Zimmer C, Neff F, Scheipl F, Pelisek J, et al. Thrombus histology suggests cardioembolic cause in cryptogenic stroke. Stroke 2016;47:1864-1871.

123. Liao $Y$, Guan $M$, Liang D, Shi $Y$, Liu J, Zeng $X$, et al. Differences in pathological composition among large artery occlusion cerebral thrombi, valvular heart disease atrial thrombi and carotid endarterectomy plaques. Front Neurol 2020;11:811.

124. Xue Y, Zhao Y, Cao J, Zhu XC, Shao HM, Chen RH, et al. Exploration of thrombus histological composition and clinical effect in mechanical thrombectomy of acute ischemic stroke. Zhonghua Yi Xue Za Zhi 2018;98:3697-3700.

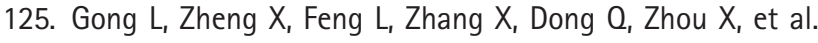
Bridging therapy versus direct mechanical thrombectomy in patients with acute ischemic stroke due to middle cerebral artery occlusion: a clinical- histological analysis of retrieved thrombi. Cell Transplant 2019;28:684-690.

126. Berndt $M$, Prothmann $S$, Maegerlein $C$, Oberdieck $P$, Zimmer $C$, Hegge $B$, et al. Artificial stroke clots: how wide is the gap to the real world? World Neurosurg 2018;110:e90-e99.

127. Bhaskar S, Saab J, Cappelen-Smith C, Cordato D, Cheung A, Manning $N$, et al. Cryptogenic stroke is linked to cardioembolic aetiology: a histopathological study of thrombus retrieved after endovascular thrombectomy. Eur J Neurol 2019; 26:20.

128. Meng L, Wang $H$, Yang $H$, Zhang $X$, Zhang $Q$, Dong $Q$, et al. Nomogram to predict poor outcome after mechanical thrombectomy at older age and histological analysis of thrombus composition. Oxid Med Cell Longev 2020;2020:8823283.

129. Wolpert F, Kulcsár Z, Hänsel M, Rushing $E_{1}$ Seystahl $K$, Schweizer J, et al. Embolization of tumor cells is rare in patients with systemic cancer and cerebral large vessel occlusion. Eur J Neuro/ 2020;27:2041-2046.

130. Hinman JD, Rao NM, Yallapragada A, Capri J, Souda $P_{1}$ Whitelegge J, et al. Drip, ship, and grip, then slice and dice: comprehensive stroke center management of cervical and intracranial emboli. Front Neurol 2013;4:104.

131. Ambrosioni J, Urra $X_{1}$ Hernández-Meneses $M$, Almela $M$, Falces $C_{1}$ Tellez $A$, et al. Mechanical thrombectomy for acute ischemic stroke secondary to infective endocarditis. Clin Infect Dis 2018;66:1286-1289.

132. Bain MD, Hussain MS, Gonugunta V, Katzan I, Gupta R. Successful recanalization of a septic embolus with a balloon mounted stent after failed mechanical thrombectomy. J Neuroimaging $2011 ; 21: 170-172$.

133. Distefano $M$, Calandrelli $R$, Arena V, Pedicelli A, Della Marca G, Pilato F. A puzzling case of cryptogenic stroke. J Stroke Cerebrovasc Dis 2019;28:e33-e35.

134. Nakanishi $K$, Kawano $H$, Amano $T$, Omori $Y$, Kanma H, Hirano T. Stroke due to infective endocarditis diagnosed by the retrieved thrombus: a case report. Rinsho Shinkeigaku 2018; 58:35-40.

135. Sukumaran S, Jayadevan ER, Mandilya A, Sreedharan SE, Harikrishnan S, Radhakrishnan N, et al. Successful mechanical thrombectomy of acute middle cerebral artery occlusion due to vegetation from infective endocarditis. Neurol India 2012; 60:239-240.

136. Sgreccia A, Carità G, Coskun O, Maria FD, Benamer H, Tisserand $M$, et al. Acute ischemic stroke treated with mechanical thrombectomy and fungal endocarditis: a case report and systematic review of the literature. J Neuroradiol 2020;47: 386-392.

137. Katano T, Sakamoto $Y$, Kunugi $S$, Nishiyama $Y$, Shimizu $A$, Kimura $K$. A fungus in a thrombus by mechanical thrombectomy in acute cerebral infarction: a case report. Rinsho Shinkeigaku 2020;60:340-345.

138. Scharf EL, Cloft HJ, Wijdicks E. Mucor thrombus. Neurocrit Care 2016;24:268-272.

139. Matsumoto $N$, Takahashi $M$, Katano $T$, Kutsuna $A$, Kanamaru T, Sakamoto $Y$, et al. Cholesterol crystal in thrombus removed by mechanical thrombectomy should be a strong marker for aortogenic embolic stroke. J Stroke Cerebrovasc Dis 2020;29: 105178.

140. Usui $G$, Hashimoto $H$, Sugiura $Y$, Nishi $Y$, Kusakabe $M$, Horiuchi $H$, et al. Aortogenic embolic stroke diagnosed by a pathological examination of endovascularly removed thrombus: an autopsy report. Intern Med 2019;58:2851-2855.

141. Koneru S, Nogueira RG, Osehobo E, Oprea-Ilies G, Al-Bayati $A R$, Brinjikji $W$, et al. Clot composition in retrieved thrombi after mechanical thrombectomy in strokes due to carotid web. J Neurointerv Surg 2021;13:530-533.

142. Mönch $S$, Boeckh-Behrens $T$, Berndt M, Maegerlein C, Wunderlich S, Zimmer $C$, et al. Angiographic baseline proximal thrombus appearance of M1/M2 occlusions in mechanical thrombectomy. Clin Neuroradiol 2021;31:189-196.

143. Wei L, Zhu Y, Deng J, Li Y, Li M, Lu H, et al. Visualization of thrombus enhancement on thin-slab maximum intensity pro- 
jection of CT angiography: an imaging sign for predicting stroke source and thrombus compositions. Radiology 2021;298:374-381.

144. Patel TR, Fricano $S$, Waqas $M$, Tso M, Dmytriw AA, Mokin M, et al. Increased perviousness on $\mathrm{CT}$ for acute ischemic stroke is associated with fibrin/platelet-rich clots. AJNR Am J Neuroradiol 2021;42:57-64.

145. Berndt M, Poppert H, Steiger K, Pelisek J, Oberdieck P, Mae-

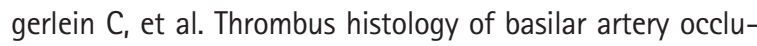
sions : are there differences to the anterior circulation? Clin Neuroradiol 2021;31:753-761.

146. Berndt $M$, Friedrich $B$, Maegerlein $C$, Moench $S$, Hedderich $D$, Lehm $M$, et al. Thrombus permeability in admission computed tomographic imaging indicates stroke pathogenesis based on thrombus histology. Stroke 2018;49:2674-2682.

147. Brinjikji W, Nogueira RG, Kvamme P, Layton KF, Delgado Almandoz JE, Hanel RA, et al. Association between clot composition and stroke origin in mechanical thrombectomy patients: analysis of the Stroke Thromboembolism Registry of Imaging and Pathology. J Neurointerv Surg 2021;13:594-598.

148. Smith WS, Furlan AJ. Brief history of endovascular acute isch- emic stroke treatment. Stroke 2016;47:e23-e26.

149. Saver JL. Clinical practice: cryptogenic stroke. N Engl J Med 2016;374:2065-2074.

150. Roessler FC, Kalms N, Jann F, Kemmling A, Ribbat-Idel J, Stellmacher $F$, et al. First approach to distinguish between cardiac and arteriosclerotic emboli of individual stroke patients applying the histological THROMBEX-classification rule. Sci Rep $2021 ; 11: 8433$.

151. Kim JM, Byun JS, Kim J, Park MS, Hong SA, Nam TK, et al. Analysis of microRNA signatures in ischemic stroke thrombus. J Neurointerv Surg 2021 Jul 8 [Epub]. https://doi.org/10.1136/ neurintsurg-2021-017597.

152. Abbasi M, Fitzgerald S, Ayers-Ringler J, Espina V, Mueller $C$, Rucker $\mathrm{S}$, et al. Proteomic analysis of cardioembolic and large artery atherosclerotic clots using reverse phase protein array technology reveals key cellular interactions within clot microenvironments. Cureus 2021;13:e13499.

153. Suissa L, Guigonis JM, Graslin F, Robinet-Borgomano $E_{1}$ Chau Y, Sedat J, et al. Combined omic analyzes of cerebral thrombi: a new molecular approach to identify cardioembolic stroke origin. Stroke 2021;52:2892-2901. 
Supplementary Table 1. Studies included in the qualitative synthesis

\begin{tabular}{|c|c|c|c|c|c|c|c|}
\hline Study & Type & $\begin{array}{l}\text { Sample } \\
\text { size }\end{array}$ & $\begin{array}{l}\text { Physical } \\
\text { analysis }\end{array}$ & Histopathology & $\begin{array}{c}\text { Biological } \\
\text { analysis }\end{array}$ & Microbiology & Diagnostic \\
\hline Abdel-Wahed et al. (2019) Am J Med ${ }^{14}$ & Case report & 1 & Yes & Yes & No & Yes & $\begin{array}{l}\text { Atypical etiology; } \\
\text { Underlying pathology }\end{array}$ \\
\hline Ahn et al. (2016) Int J Stroke ${ }^{57}$ & Cohort & 36 & No & Yes & No & No & TOAST \\
\hline Almekhlafi et al. (2008) Ann Neurol ${ }^{43}$ & Case series & 5 & Yes & Yes & No & No & None \\
\hline Ambrosioni et al. (2018) Clin Infect Dis ${ }^{131}$ & Case series & 6 & No & No & No & Yes & $\begin{array}{l}\text { Atypical etiology; } \\
\text { Underlying pathology }\end{array}$ \\
\hline Anuwatworn et al. (2015) JACC Cardiovasc Interv²4 & Case report & 1 & Yes & Yes & No & No & $\begin{array}{l}\text { Atypical etiology; } \\
\text { Underlying pathology }\end{array}$ \\
\hline Baek et al. (2018) Ann Clin Transl Neurol ${ }^{112}$ & Cohort & 82 & No & No & Yes & No & TOAST \\
\hline Bain et al. (2011) J Neuroimaging ${ }^{132}$ & Case report & 1 & No & Yes & No & Yes & $\begin{array}{l}\text { Atypical etiology; } \\
\text { Underlying pathology }\end{array}$ \\
\hline Benson et al. (2020) J Neurolntervent Surg ${ }^{58}$ & Cohort & 57 & No & Yes & No & No & None \\
\hline Berndt et al. (2018) World Neurosurg ${ }^{126}$ & Cohort & 137 & No & Yes & No & No & TOAST \\
\hline Berndt et al. (2018) Stroke ${ }^{146}$ & Cohort & 32 & No & Yes & No & No & None \\
\hline Berndt et al. (2021) Clin Neuroradiol ${ }^{145}$ & Cohort & 59 & No & Yes & No & No & None \\
\hline Bhaskar et al. (2019) Eur J Neurol ${ }^{127}$ & Cohort & 85 & No & Yes & No & No & TOAST \\
\hline Bhaskar et al. (2019) Can J Neurol Sci ${ }^{102}$ & Case series & 4 & No & Yes & No & Yes & $\begin{array}{l}\text { Atypical etiology; } \\
\text { Underlying pathology }\end{array}$ \\
\hline Biraschi et al. (2016) J Stroke Cerebrovasc Dis ${ }^{15}$ & Case report & 1 & Yes & Yes & No & No & $\begin{array}{l}\text { Atypical etiology; } \\
\text { Underlying pathology }\end{array}$ \\
\hline Boeckh-Behrens et al. (2016) Clin Neuroradio ${ }^{89}$ & Cohort & 34 & No & Yes & No & No & TOAST \\
\hline Boeckh-Behrens et al. (2016) Stroke ${ }^{122}$ & Cohort & 137 & No & Yes & No & No & TOAST \\
\hline Bourcier et al. (2020) J Stroke Cerebrovasc Dis $^{35}$ & Cohort & 139 & Yes & No & No & No & None \\
\hline Brinjikji et al. (2020) Stroke ${ }^{59}$ & Cohort & 1,022 & No & Yes & No & No & TOAST \\
\hline Chapot et al. (2006) Am J Neuroradiol ${ }^{25}$ & Case report & 1 & Yes & Yes & No & No & Atypical etiology \\
\hline Chen et al. (2021) Front Pharmaco ${ }^{99}$ & Cohort & 30 & No & Yes & Yes & No & None \\
\hline Choi et al. (2018) Stroke ${ }^{37}$ & Cohort & 52 & Yes & Yes & No & No & None \\
\hline Chueh et al. (2011) Am J Neuroradiol ${ }^{44}$ & Cohort & 4 & Yes & Yes & No & No & None \\
\hline Cline et al. (2013) J Neurolntervent Surg ${ }^{106}$ & Cohort & 16 & No & Yes & No & No & None \\
\hline Darcourt et al. (2021) Int J Stroke ${ }^{87}$ & Cohort & 102 & No & Yes & No & No & None \\
\hline Dargazanli et al. (2016) PLoS ONE ${ }^{90}$ & Cohort & 54 & No & Yes & No & No & TOAST \\
\hline Dargazanli et al. (2020) Front Neurol ${ }^{115}$ & Cohort & 60 & No & No & Yes & No & TOAST \\
\hline Deng et al. (2020) Neurosci Lett ${ }^{94}$ & Cohort & 46 & No & Yes & No & No & Underlying pathology \\
\hline Di Meglio et al. (2020) Eur J Neurol ${ }^{119}$ & Cohort & 84 & No & No & Yes & No & None \\
\hline Di Meglio et al. (2020) Stroke ${ }^{118}$ & Cohort & 250 & No & No & Yes & No & TOAST \\
\hline Di Meglio et al. (2019) Neurology ${ }^{63}$ & Cohort & 199 & No & Yes & No & No & None \\
\hline Distefano et al. (2019) J Stroke Cerebrovasc Dis ${ }^{133}$ & Case report & 1 & No & Yes & No & Yes & $\begin{array}{l}\text { Atypical etiology; } \\
\text { Underlying pathology }\end{array}$ \\
\hline Donnerstag et al. (2021) Intervent Neuroradiol ${ }^{91}$ & Cohort & 302 & No & Yes & No & No & None \\
\hline Douglas et al. (2020) J Neurolntervent Surg ${ }^{60}$ & Cohort & 91 & No & Yes & No & No & None \\
\hline Ducroux et al. (2018) Stroke ${ }^{95}$ & Cohort & 108 & No & Yes & Yes & No & None \\
\hline Duffy et al. (2019) Stroke ${ }^{61}$ & Cohort & 106 & No & Yes & No & No & None \\
\hline Elijovich et al. (2018) Stroke ${ }^{75}$ & Cohort & 25 & No & Yes & Yes & No & None \\
\hline Elodie et al. (2019) J Neurol Sci ${ }^{26}$ & Case report & 1 & Yes & No & No & Yes & $\begin{array}{l}\text { Atypical etiology; } \\
\text { Underlying pathology }\end{array}$ \\
\hline Essig et al. (2020) Int J Mol Sci ${ }^{76}$ & Cohort & 37 & No & Yes & No & No & TOAST \\
\hline Fassa et al. (2014) Circ Cardiovasc Interv & Case report & 1 & Yes & Yes & No & No & Atypical etiology \\
\hline
\end{tabular}


Supplementary Table 1. Continued

\begin{tabular}{|c|c|c|c|c|c|c|c|}
\hline Study & Type & $\begin{array}{l}\text { Sample } \\
\text { size }\end{array}$ & $\begin{array}{l}\text { Physical } \\
\text { analysis }\end{array}$ & Histopathology & $\begin{array}{l}\text { Biological } \\
\text { analysis }\end{array}$ & Microbiology & Diagnostic \\
\hline Fitzgerald et al. (2019) Stroke ${ }^{50}$ & Cohort & 105 & No & Yes & No & No & TOAST \\
\hline Fitzgerald et al. (2021) J Stroke Cerebrovasc Dis ${ }^{40}$ & Cohort & 550 & Yes & No & No & No & TOAST \\
\hline Fitzgerald et al. (2019) PLoS ONE ${ }^{48}$ & Cohort & 50 & No & Yes & No & No & None \\
\hline Fitzgerald et al. (2020) J Neurolntervent Surg ${ }^{39}$ & Cohort & 612 & Yes & Yes & No & No & TOAST \\
\hline Fitzgerald et al. (2019) J Neurolntervent Surg ${ }^{49}$ & Cohort & 85 & No & Yes & No & No & None \\
\hline Fitzpatrick et al. (2018) J Neurolntervent Surg ${ }^{28}$ & Case series & 3 & Yes & Yes & No & No & Atypical etiology \\
\hline Fu et al. (2020) Stroke ${ }^{38}$ & Cohort & 152 & Yes & Yes & No & No & $\begin{array}{l}\text { Atypical etiology; } \\
\text { Underlying pathology }\end{array}$ \\
\hline Funatsu et al. (2019) J Neurolntervent Surg ${ }^{101}$ & Cohort & 150 & No & Yes & No & No & None \\
\hline Garcia-Ptacek et al. (2014) J Neurolntervent Surg ${ }^{29}$ & Case report & 2 & Yes & Yes & No & No & $\begin{array}{l}\text { Atypical etiology; } \\
\text { Underlying pathology }\end{array}$ \\
\hline Genchi et al. (2020) J Neurol Sci ${ }^{30}$ & Case report & 1 & Yes & Yes & No & No & Atypical etiology \\
\hline Goebel et al. (2020) Am J Neuroradiol ${ }^{67}$ & Cohort & 85 & No & Yes & No & No & TOAST \\
\hline Gong et al. (2019) Cell Transplant ${ }^{125}$ & Cohort & 45 & No & Yes & No & No & TOAST \\
\hline Gurkas et al. (2019) Stroke ${ }^{77}$ & Cohort & 111 & No & Yes & No & No & None \\
\hline Hanning et al. (2021) J Neurolntervent Surg ${ }^{88}$ & Cohort & 112 & No & Yes & No & No & None \\
\hline Hashimoto et al. (2016) Stroke ${ }^{78}$ & Cohort & 83 & No & Yes & No & No & None \\
\hline $\begin{array}{l}\text { Hernández-Fernández et al. (2017) Cardiovasc } \\
\text { Intervent Radiol }{ }^{109}\end{array}$ & Cohort & 65 & No & Yes & No & Yes & $\begin{array}{l}\text { Atypical etiology; } \\
\text { Underlying pathology }\end{array}$ \\
\hline Hinman et al. (2013) Front Neurol ${ }^{130}$ & Case report & 1 & No & Yes & Yes & No & Atypical etiology \\
\hline Horie et al. (2019) World Neurosurg ${ }^{42}$ & Cohort & 65 & No & Yes & No & No & None \\
\hline Hund et al. (2019) J Cereb Blood Flow Metab ${ }^{104}$ & Cohort & 281 & No & Yes & No & No & None \\
\hline Itsekson Hayosh et al. (2020) J Neurolntervent Surg ${ }^{121}$ & Cohort & 68 & No & No & Yes & No & TOAST \\
\hline Juega et al. (2019) Stroke $\mathrm{e}^{120}$ & Cohort & 40 & No & No & Yes & No & TOAST \\
\hline Kaesmacher et al. (2017) Am J Neuroradio $\left.\right|^{92}$ & Cohort & 85 & No & Yes & No & No & None \\
\hline Kan et al. (2012) World Neurosurg ${ }^{31}$ & Case report & 1 & Yes & No & No & Yes & $\begin{array}{l}\text { Atypical etiology; } \\
\text { Underlying pathology }\end{array}$ \\
\hline Katano et al. (2020) Clin Neurol ${ }^{137}$ & Case report & 1 & No & Yes & No & Yes & $\begin{array}{l}\text { Atypical etiology; } \\
\text { Underlying pathology }\end{array}$ \\
\hline Khashim et al. (2019) Interv Neuroradiol ${ }^{108}$ & Cohort & 20 & No & No & No & Yes & None \\
\hline Khismatullin et al. (2020) BioNanoScience ${ }^{62}$ & Case series & 3 & No & Yes & No & No & None \\
\hline Kim et al. (2020) J Clin Neurosci ${ }^{51}$ & Cohort & 52 & No & Yes & No & No & TOAST \\
\hline Kim et al. (2014) Neurointervention ${ }^{32}$ & Case report & 1 & Yes & Yes & No & Yes & $\begin{array}{l}\text { Atypical etiology; } \\
\text { Underlying pathology }\end{array}$ \\
\hline Kim et al. (2015) Am J Neuroradiol ${ }^{72}$ & Cohort & 37 & No & Yes & No & No & TOAST \\
\hline Koneru et al. (2021) J Neurolntervent Surg ${ }^{141}$ & Case series & 3 & No & Yes & No & No & $\begin{array}{l}\text { Atypical etiology; } \\
\text { Underlying pathology }\end{array}$ \\
\hline Krajičková et al. (2018) Circ J98 & Cohort & 80 & No & Yes & No & No & None \\
\hline Laridan et al. (2017) Ann Neurol93 & Cohort & 68 & No & Yes & No & No & TOAST \\
\hline Li et al. (2020) BMC Neurology ${ }^{107}$ & Case report & 2 & No & Yes & No & No & None \\
\hline Liao et al. (2020) Front Neurol ${ }^{123}$ & Cohort & 88 & No & Yes & No & No & TOAST \\
\hline Liebeskind et al. (2011) Stroke ${ }^{79}$ & Cohort & 50 & No & Yes & No & No & None \\
\hline Liu et al. (2020) J Neurosurg ${ }^{45}$ & Cohort & 16 & Yes & Yes & No & No & None \\
\hline Liu et al. (2020) Thromb Res ${ }^{80}$ & Cohort & 84 & No & Yes & No & No & None \\
\hline López-Cancio et al. (2013) Cerebrovasc Dis $^{74}$ & Cohort & 15 & No & Yes & No & No & None \\
\hline Lopez-Pedrera et al. (2020) Res Pract Thromb Haemost ${ }^{116}$ & Cohort & 50 & No & No & Yes & No & None \\
\hline
\end{tabular}


Supplementary Table 1. Continued

\begin{tabular}{|c|c|c|c|c|c|c|c|}
\hline Study & Type & $\begin{array}{l}\text { Sample } \\
\text { size }\end{array}$ & $\begin{array}{l}\text { Physical } \\
\text { analysis }\end{array}$ & Histopathology & $\begin{array}{c}\text { Biological } \\
\text { analysis }\end{array}$ & Microbiology & Diagnostic \\
\hline Maegerlein et al. (2018) Intervent Neuroradiol $\left.\right|^{81}$ & Cohort & 64 & No & Yes & No & No & None \\
\hline Maekawa et al. (2018) Cerebrovasc Dis Extra ${ }^{82}$ & Cohort & 43 & No & Yes & No & No & TOAST \\
\hline Marder et al. (2006) Stroke ${ }^{7}$ & Cohort & 25 & No & Yes & No & Yes & $\begin{array}{l}\text { Atypical etiology; None; } \\
\text { Underlying pathology }\end{array}$ \\
\hline Matsumoto et al. (2016) J Stroke Cerebrovasc $\mathrm{Dis}^{33}$ & Case report & 2 & Yes & Yes & No & No & $\begin{array}{l}\text { Atypical etiology; } \\
\text { Underlying pathology }\end{array}$ \\
\hline Matsumoto et al. (2020) J Stroke Cerebrovasc Dis ${ }^{139}$ & Case report & 1 & No & Yes & No & No & Atypical etiology \\
\hline Meher et al. (2018) Int J Stroke $e^{47}$ & Cohort & 19 & Yes & Yes & No & No & None \\
\hline Mehta et al. (2019) J Neurolntervent Surg ${ }^{103}$ & Cohort & 92 & No & Yes & No & No & None \\
\hline Meng et al. (2020) Oxid Med Cell Longev ${ }^{128}$ & Cohort & 147 & No & Yes & No & No & None \\
\hline Mereuta et al. (2020) Stroke ${ }^{100}$ & Cohort & 79 & No & Yes & No & No & TOAST \\
\hline Mereuta et al. (2021) J Neurolntervent Surg ${ }^{56}$ & Cohort & 10 & No & Yes & No & No & None \\
\hline Mönch et al. (2021) Clin Neuroradiol ${ }^{142}$ & Cohort & 69 & No & Yes & No & No & None \\
\hline Muñoz et al. (2018) Int J Mol Sci114 & Cohort & 4 & No & No & Yes & No & None \\
\hline Nakanishi et al. (2018) Clin Neurol ${ }^{134}$ & Case report & 1 & No & No & No & Yes & $\begin{array}{l}\text { Atypical etiology; } \\
\text { Underlying pathology }\end{array}$ \\
\hline Niesten et al. (2014) PLoS ONE ${ }^{64}$ & Cohort & 22 & No & Yes & No & No & TOAST \\
\hline Nouh et al. (2020) BMC Neurology $\mathrm{y}^{73}$ & Cohort & 33 & No & Yes & No & No & TOAST \\
\hline Novotny et al. (2020) Neurology66 & Cohort & 71 & No & Yes & No & No & TOAST \\
\hline Park et al. (2019) Ann Neurol ${ }^{65}$ & Cohort & 48 & No & Yes & No & No & $\begin{array}{l}\text { Atypical etiology; } \\
\text { Underlying pathology }\end{array}$ \\
\hline Patel et al. (2021) Am J Neuroradiol ${ }^{144}$ & Cohort & 40 & No & Yes & No & No & None \\
\hline Patrakka et al. (2019) J Am Heart Assoc ${ }^{110}$ & Cohort & 75 & No & No & No & Yes & None \\
\hline Peña-Martínez et al. (2019) Stroke ${ }^{71}$ & Cohort & 10 & No & Yes & Yes & No & None \\
\hline Pisano et al. (2020) J Stroke Cerebrovasc Dis ${ }^{34}$ & Case report & 1 & Yes & No & No & No & $\begin{array}{l}\text { Atypical etiology; } \\
\text { Underlying pathology }\end{array}$ \\
\hline Prochazka et al. (2018) Med Sci Monit ${ }^{97}$ & Cohort & 90 & No & Yes & No & No & None \\
\hline Qureshi et al. (2016) J Vasc Intervent Neurol ${ }^{83}$ & Cohort & 18 & No & Yes & No & No & None \\
\hline Rao et al. (2017) Front Neurol ${ }^{113}$ & Cohort & 20 & No & No & Yes & No & None \\
\hline Rossi et al. (2021) J Thromb Thrombolysis ${ }^{41}$ & Cohort & 550 & Yes & No & No & No & None \\
\hline Salam et al. (2018) J Stroke Cerebrovasc Dis ${ }^{16}$ & Case report & 1 & Yes & Yes & No & No & $\begin{array}{l}\text { Atypical etiology; } \\
\text { Underlying pathology }\end{array}$ \\
\hline Salinas et al. (2013) JACC Cardiovasc Interv ${ }^{17}$ & Case report & 1 & Yes & No & No & No & Atypical etiology \\
\hline Sallustio et al. (2015) J Neurol Disord Stroke ${ }^{105}$ & Cohort & 28 & No & Yes & No & No & None \\
\hline Scharf et al. (2017) J Neurolntervent Surg ${ }^{18}$ & Case report & 1 & Yes & Yes & No & Yes & $\begin{array}{l}\text { Atypical etiology; } \\
\text { Underlying pathology }\end{array}$ \\
\hline Scharf et al. (2016) Neurocrit Care ${ }^{138}$ & Case report & 1 & No & No & No & Yes & $\begin{array}{l}\text { Atypical etiology; } \\
\text { Underlying pathology }\end{array}$ \\
\hline Schuhmann et al. (2016) Int J Mol Sci5 & Cohort & 37 & No & Yes & No & No & None \\
\hline Semerano et al. (2019) J Neurol ${ }^{19}$ & Case report & 1 & Yes & Yes & No & No & TOAST \\
\hline Sgreccia et al. (2020) J Neuroradiol ${ }^{136}$ & Case report & 1 & No & No & No & Yes & $\begin{array}{l}\text { Atypical etiology; } \\
\text { Underlying pathology }\end{array}$ \\
\hline Sgreccia et al. (2019) J Neurolntervent Surg ${ }^{36}$ & Cohort & 255 & Yes & No & No & No & $\begin{array}{l}\text { Atypical etiology; } \\
\text { Underlying pathology }\end{array}$ \\
\hline Shin et al. (2018) PLoS ONE ${ }^{84}$ & Cohort & 93 & No & Yes & No & No & TOAST \\
\hline Simons et al. (2015) J Neuroradiol ${ }^{85}$ & Cohort & 40 & No & Yes & No & No & None \\
\hline Singh et al. (2013) Stroke ${ }^{86}$ & Cohort & 48 & No & Yes & No & No & None \\
\hline
\end{tabular}


Supplementary Table 1. Continued

\begin{tabular}{|c|c|c|c|c|c|c|c|}
\hline Study & Type & $\begin{array}{l}\text { Sample } \\
\text { size }\end{array}$ & $\begin{array}{l}\text { Physical } \\
\text { analysis }\end{array}$ & Histopathology & $\begin{array}{c}\text { Biological } \\
\text { analysis }\end{array}$ & Microbiology & Diagnostic \\
\hline Sporns et al. (2021) J Neurolntervent Surg ${ }^{68}$ & Cohort & 163 & No & Yes & No & No & None \\
\hline Sporns et al. (2017) Stroke $e^{96}$ & Cohort & 187 & No & Yes & No & No & TOAST \\
\hline Sporns et al. (2017) Cerebrovasc Dis $^{70}$ & Cohort & 180 & No & Yes & No & No & None \\
\hline Sporns et al. (2019) Stroke ${ }^{69}$ & Cohort & 163 & No & Yes & No & No & None \\
\hline Staessens et al. (2020) Haematologica ${ }^{53}$ & Cohort & 177 & No & Yes & No & No & None \\
\hline Suissa et al. (2020) Metabolites ${ }^{117}$ & Cohort & 41 & No & No & Yes & No & None \\
\hline Sukumaran et al. (2012) Neurol India ${ }^{135}$ & Case report & 1 & No & Yes & No & Yes & $\begin{array}{l}\text { Atypical etiology; } \\
\text { Underlying pathology }\end{array}$ \\
\hline Tejada et al. (2014) J Neurolntervent Surg ${ }^{20}$ & Case report & 1 & Yes & Yes & No & No & $\begin{array}{l}\text { Atypical etiology; } \\
\text { Underlying pathology }\end{array}$ \\
\hline Thomas et al. (2017) J Neurolntervent Surg ${ }^{21}$ & Case report & 1 & Yes & Yes & No & No & $\begin{array}{l}\text { Atypical etiology; } \\
\text { Underlying pathology }\end{array}$ \\
\hline Usui et al. (2019) Intern Med ${ }^{140}$ & Case report & 1 & No & Yes & No & No & Atypical etiology \\
\hline Vajpeyee et al. (2021) Neurointervention ${ }^{111}$ & Cohort & 4 & No & No & No & Yes & TOAST \\
\hline Valente et al. (2019) J Clin Neurosci ${ }^{22}$ & Case report & 1 & Yes & Yes & No & Yes & $\begin{array}{l}\text { Atypical etiology; } \\
\text { Underlying pathology }\end{array}$ \\
\hline Vidmar et al. (2019) Radiol Oncol ${ }^{46}$ & Cohort & 17 & Yes & No & No & No & None \\
\hline Wei et al. (2021) Radiology ${ }^{143}$ & Cohort & 77 & No & Yes & No & No & None \\
\hline Wollenweber et al. (2016) Neurology $y^{23}$ & Case report & 1 & Yes & Yes & No & No & Atypical etiology \\
\hline Wolpert et al. (2020) Eur J Neurol' ${ }^{129}$ & Cohort & 32 & No & Yes & No & No & $\begin{array}{l}\text { Atypical etiology; } \\
\text { Underlying pathology }\end{array}$ \\
\hline Xue et al. (2018) Natl Med J China ${ }^{124}$ & Cohort & 58 & No & Yes & No & No & TOAST \\
\hline Ye et al. (2020) Interv Neuroradiol ${ }^{55}$ & Cohort & 52 & No & Yes & No & No & Underlying pathology \\
\hline Ye et al. (2020) Clin Neurol Neurosurg ${ }^{54}$ & Cohort & 54 & No & Yes & No & No & None \\
\hline
\end{tabular}

TOAST, Trial of ORG 10172 in Acute Stroke Treatment. 
Supplementary Table 2. Cohort studies: thrombus composition and TOAST stroke etiology or underlying pathology

\begin{tabular}{|c|c|c|c|c|c|}
\hline Study & $\begin{array}{l}\text { Sample size } \\
\text { (clots/ } \\
\text { patients) }\end{array}$ & Analysis & $\begin{array}{l}\text { Thrombus } \\
\text { composition items }\end{array}$ & $\begin{array}{l}\text { Etiology groups } \\
\text { (patients) }\end{array}$ & $\begin{array}{c}\text { Association composition-etiology or } \\
\text { underlying pathology }\end{array}$ \\
\hline $\begin{array}{l}\text { Ahn et al. (2016) } \\
\text { Int J Stroke }\end{array}$ & 36 & Histopathology & $\begin{array}{l}\mathrm{RBC} \text { and } \mathrm{FBR} \\
\text { proportions }\end{array}$ & $\begin{array}{l}\text { LAA (8), CE (22), } \\
\text { and CRY (6) }\end{array}$ & $\begin{array}{l}\text { RBCs most abundant }(56.9 \% \pm 12.2 \%) \text { in LAA, higher } \\
\text { than CE. FBR most abundant }(39.5 \% \pm 13.5 \%) \text { in CE, } \\
\text { higher than LAA. Similar composition in CRY and CE }\end{array}$ \\
\hline $\begin{array}{l}\text { Baek et al. (2018) } \\
\text { Ann Clin Transl Neurol }{ }^{112}\end{array}$ & 82 & $\begin{array}{l}\text { Biomolecular } \\
\text { RTqPCR }\end{array}$ & $\begin{array}{l}\text { Expression of } \\
\text { inflammatory } \\
\text { mediators }\end{array}$ & $\begin{array}{l}\text { LAA (9), CE (51), } \\
\text { and CRY (22) }\end{array}$ & $\begin{array}{l}\text { Higher IL-1 } \beta \text { expression in LAA than in both CE and } \\
\text { CRY. Similar expression in CRY and CE }\end{array}$ \\
\hline $\begin{array}{l}\text { Berndt et al. (2018) } \\
\text { World Neurosurg }\end{array}$ & 137 & Histopathology & FP/RBC ratio & $\begin{array}{l}\text { LAA (22), CE (67), } \\
\text { ODC (11), and CRY } \\
(36)\end{array}$ & Higher FP/RBC in $\mathrm{CE}+\mathrm{CRY}$ than non-CE $(\mathrm{LAA}+\mathrm{ODC})$ \\
\hline $\begin{array}{l}\text { Bhaskar et al. (2019) } \\
\text { Eur J Neurol }{ }^{127}\end{array}$ & 85 & Histopathology & $\begin{array}{l}\mathrm{RBC}, \mathrm{FP} \text {, and } \mathrm{WBC} \\
\text { proportions }\end{array}$ & $\begin{array}{l}\mathrm{CE}, \text { non-CE, } \\
\text { and } \mathrm{CRY}\end{array}$ & $\begin{array}{l}\text { RBC }(26 \%), F P(61 \%) \text { and WBC }(11 \%) \text { proportions in CE } \\
\text { similar to RBC }(28 \%), \mathrm{FP}(64 \%) \text { and WBC }(9 \%) \\
\text { proportions in CRY. Different proportions in non-CE }\end{array}$ \\
\hline $\begin{array}{l}\text { Boeckh-Behrens et al. (2016) } \\
\text { Clin Neuroradiolo }\end{array}$ & 34 & Histopathology & $\begin{array}{l}\mathrm{RBC}, \mathrm{FP} \text {, and } \mathrm{WBC} \\
\text { proportions }\end{array}$ & $\begin{array}{l}\text { LAA (3), CE (16), } \\
\text { ODC (6), and CRY } \\
\text { (9) }\end{array}$ & Higher proportion of WBCs in CE than in LAA or CRY \\
\hline $\begin{array}{l}\text { Boeckh-Behrens et al. (2016) } \\
\text { Stroke }\end{array}$ & 137 & Histopathology & $\begin{array}{l}\mathrm{RBC}, \mathrm{FP} \text {, and } \mathrm{WBC} \\
\text { proportions }\end{array}$ & $\begin{array}{l}\text { LAA (22), CE (67), } \\
\text { ODC (11), and CRY } \\
\text { (36) }\end{array}$ & $\begin{array}{l}\text { Different composition in CE (RBC } 38.3 \% \pm 20.0 \% \text {, } \\
\text { FP } 52.6 \% \pm 18.6 \% \text { and WBC } 9.1 \% \pm 6.4 \% \text { ) and in non- } \\
\text { CE (LAA+ODE) (RBC } 52.7 \% \pm 25.2 \%, \text { FP } 40.9 \% \pm 23.3 \% \text {, } \\
\text { and WBC } 6.5 \% \pm 3.8 \%) \text {. Similar composition in CRY } \\
\text { (RBC } 42.0 \% \pm 21.4 \% \text {, FP } 50.8 \% \pm 20.8 \% \text {, and WBC } \\
7.1 \% \pm 4.5 \%) \text { and in CE }\end{array}$ \\
\hline Brinjikji et al. (2020) Stroke ${ }^{59}$ & 1,022 & Histopathology & PLT proportion & LAA and CE & $\begin{array}{l}\text { Higher PLT content in LAA (PLT-rich clots [55.0\%], PLT- } \\
\text { area }[22.1 \%]) \text { than in CE (PLT-rich clots [21.2\%], PLT- } \\
\text { area }[13.9 \%])\end{array}$ \\
\hline $\begin{array}{l}\text { Dargazanli et al. (2016) } \\
\text { PLOS One }\end{array}$ & 54 & Histopathology & CD3+ T-cell count & $\begin{array}{l}\text { LAA (10), CE (25), } \\
\text { and other causes } \\
\text { (ODC+CRY, 19) }\end{array}$ & $\begin{array}{l}\text { Higher T-cell count in LAA }(53.60 \pm 28.78) \text { than in both } \\
\text { CE }(20.08 \pm 15.66) \text { or other causes }(21.77 \pm 18.31)\end{array}$ \\
\hline $\begin{array}{l}\text { Dargazanli et al. (2020) } \\
\text { Front Neurol }{ }^{115}\end{array}$ & 60 & $\begin{array}{l}\text { Biomolecular } \\
\text { Proteomics }\end{array}$ & Relative protein & $\begin{array}{l}\text { LAA (28) and CE } \\
(32)\end{array}$ & Coagulation factor XIII associated with CE \\
\hline $\begin{array}{l}\text { Deng et al. (2020) } \\
\text { Neurosci Lett }{ }^{94}\end{array}$ & 46 & Histopathology & $\begin{array}{l}\text { NETs (H3Cit) } \\
\text { proportion }\end{array}$ & $\begin{array}{l}\text { NG (28), AHG (9), } \\
\text { and DM (9) }\end{array}$ & Higher NETs proportion in both AHG and DM than in NG \\
\hline $\begin{array}{l}\text { Di Meglio et al. (2020) } \\
\text { Stroke }\end{array}$ & 250 & Biochemical & $\begin{array}{l}\text { GP (glycoprotein) } \\
\text { VI, heme, and } \\
\text { DNA contents }\end{array}$ & $\begin{array}{l}\text { CE (142), non-CE } \\
\text { (33), and ESUS } \\
(75)\end{array}$ & $\begin{array}{l}\text { CE richer in DNA (35.8 ng/mg), i.e., more leukocytes, and } \\
\text { poorer in GP VI }(0.104 \mathrm{ng} / \mathrm{mg}) \text {, i.e., less PLTs, than non- } \\
\text { CE (DNA } 13.8 \mathrm{ng} / \mathrm{mg} \text {; GP VI } 0.117 \mathrm{ng} / \mathrm{mg})\end{array}$ \\
\hline $\begin{array}{l}\text { Essig et al. (2020) } \\
\text { Int J Mol Sci }{ }^{76}\end{array}$ & 37 & Histopathology & $\begin{array}{l}\text { Neutrophil count } \\
\text { and FBR } \\
\text { proportion }\end{array}$ & $\begin{array}{l}\text { CE (21), non-CE (7), } \\
\text { and CRY (9) }\end{array}$ & $\begin{array}{l}\text { Higher neutrophil counts in both CE }(799.1 \pm 477.6 \text { cells/ } \\
\left.\mathrm{mm}^{2}\right) \text { and CRY }\left(734.1 \pm 329.1 \mathrm{cells} / \mathrm{mm}^{2}\right) \text { compared to } \\
\text { non-CE }(376 \pm 128.5 \text { cells/mm²). Higher FBR proportion } \\
\text { in both CE }(46.1 \% \pm 29.9 \%) \text { and CRY }(46.6 \% \pm 21.8 \%) \\
\text { compared to non-CE }(25.9 \% \pm 12.1 \%)\end{array}$ \\
\hline $\begin{array}{l}\text { Fitzgerald et al. (2019) } \\
\text { Stroke }^{50}\end{array}$ & 105 & Histopathology & $\begin{array}{l}\mathrm{RBC}, \mathrm{WBC}, \mathrm{FBR} \\
\text { and PLTs+other } \\
\text { proportions }\end{array}$ & $\begin{array}{l}\text { LAA (20), CE (52), } \\
\text { ODC (12), and CRY } \\
(21)\end{array}$ & $\begin{array}{l}\text { Higher PLT content in LAA (PLT-rich clots [55.0\%], PLT- } \\
\text { area [22.1\% } \% 18.6 \%] \text { ) than in CE (PLT-rich clots } \\
[21.2 \%], \text { PLT-area [13.9\% } 014.3 \%]) \text {. More PLT-rich } \\
\text { clots in both LAA }(55.0 \%) \text { and CRY }(50.0 \%) \text { than in CE } \\
(21.2 \%)\end{array}$ \\
\hline $\begin{array}{l}\text { Fitzgerald et al. (2020) J } \\
\text { Neurolnterv Surg }\end{array}$ & 612 / 441 & Histopathology & $\begin{array}{l}\mathrm{ECA} ; \mathrm{RBC}, \text { WBC, } \\
\mathrm{FBR} \text {, PLTs+other, } \\
\text { and collagen } \\
\text { proportions }\end{array}$ & $\begin{array}{l}\text { LAA (115), CE (209), } \\
\text { ODC (16), and CRY } \\
(101)\end{array}$ & $\begin{array}{l}\text { Larger ECA in LAA }\left(54.96 \mathrm{~mm}^{2}\right) \text { than in CE }\left(33.64 \mathrm{~mm}^{2}\right) \text {, } \\
\text { ODC }\left(39.60 \mathrm{~mm}^{2}\right) \text {, and CRY }\left(32.28 \mathrm{~mm}^{2}\right) \text {. Higher RBC } \\
\text { proportion in LAA }(48.89 \%) \text { than in CE }(35.57 \%), \text { ODC } \\
(42.82 \%) \text {, and CRY }(39.08 \%) \text {. Highest proportion of } \\
\text { both FBR }(33.3 \%) \text { and PLTs+other }(28.53 \%) \text { in CE }\end{array}$ \\
\hline $\begin{array}{l}\text { Fitzgerald et al. (2021) } \\
\text { J Stroke Cerebrovasc Dis }{ }^{40}\end{array}$ & 550 & Histopathology & $\begin{array}{r}\text { ECA. Number of } \\
\text { clot fragments }\end{array}$ & $\begin{array}{l}\text { LAA (110), CE (197), } \\
\text { ODC (33), and CRY } \\
\text { (143). Excluded } \\
\text { (67) }\end{array}$ & $\begin{array}{l}\text { Larger ECA in LAA }\left(109 \mathrm{~mm}^{2}\right) \text { than in CE }\left(52 \mathrm{~mm}^{2}\right), \mathrm{ODC} \\
\left(52 \mathrm{~mm}^{2}\right) \text {, and CRY }\left(47 \mathrm{~mm}^{2}\right) \text {. Greater number of } \\
\text { fragments in LAA }(5.36) \text { than in CE }(3.72), \text { ODC (3.73), } \\
\text { and CRY (3.52) }\end{array}$ \\
\hline
\end{tabular}


Supplementary Table 2. Continued

\begin{tabular}{|c|c|c|c|c|c|}
\hline Study & $\begin{array}{l}\text { Sample size } \\
\text { (clots/ } \\
\text { patients) }\end{array}$ & Analysis & $\begin{array}{l}\text { Thrombus } \\
\text { composition items }\end{array}$ & $\begin{array}{l}\text { Etiology groups } \\
\text { (patients) }\end{array}$ & $\begin{array}{l}\text { Association composition-etiology or } \\
\text { underlying pathology }\end{array}$ \\
\hline Fu et al. (2020) Stroke ${ }^{38}$ & 152 & $\begin{array}{l}\text { Macroscopic. } \\
\text { Histopathology }\end{array}$ & $\begin{array}{l}\mathrm{RBC}, \mathrm{FP} \text {, and } \mathrm{WBC} \\
\text { proportions }\end{array}$ & $\begin{array}{l}\text { AC (19), LAA (26), } \\
\text { and CE (107) }\end{array}$ & $\begin{array}{l}\text { White gross appearance in AC vs. darker/reddish in LAA } \\
\text { or CE. Higher FP proportion in AC (85.7\%) than in LAA } \\
(42.5 \%) \text { or CE ( } 43.9 \%) \text {. Lower RBC proportion in AC } \\
(8.1 \%) \text { than in LAA (51.7\%) or CE }(52.2 \%) \text {. Lower WBC } \\
\text { proportion in AC }(1.9 \%) \text { than in LAA }(3.1 \%) \text { or CE } \\
(3.7 \%)\end{array}$ \\
\hline $\begin{array}{l}\text { Goebel et al. (2020) } \\
\text { Am J Neuroradiol }\end{array}$ & 85 & Histopathology & $\begin{array}{l}\text { RBC, WBC } \\
\text { (macrophages, } \\
\text { lymphocytes, } \\
\text { granulocytes), } \\
\text { FBR, and PLTs } \\
\text { proportions }\end{array}$ & $\begin{array}{l}\text { LAA (16), CE (51), } \\
\text { ODC (1), and ESUS } \\
(17)\end{array}$ & $\begin{array}{l}\text { Higher proportion (range) of macrophages in CE }(0.9 \% \\
[0.1 \%-3.3 \%]) \text { than in LAA }(0.3 \% \text { [0.1\%-3.8\%]) or } \\
\text { ESUS }(0.4 \%[0.0 \%-5.2 \%]) \text {. Higher proportion of PLTs } \\
\text { in CE }(19.1 \%[3.6 \%-81.1 \%]) \text { than LAA }(10.3 \%[2.3 \%- \\
25.1 \%])\end{array}$ \\
\hline $\begin{array}{l}\text { Gong et al. (2019) } \\
\text { Cell Transplant }{ }^{125}\end{array}$ & 45 & Histopathology & $\begin{array}{l}\mathrm{RBC} \text { and } \mathrm{FBR} \\
\text { proportions }\end{array}$ & LAA (9) and CE (36) & $\begin{array}{l}\text { Higher RBC proportion in CE }(69 \%) \text { than in LAA }(55.5 \%) \text {. } \\
\text { Lower FBR proportion in CE (31\%) than in LAA }(44.5 \%)\end{array}$ \\
\hline $\begin{array}{l}\text { Hernández-Fernández et al. } \\
\text { (2017) Cardiovasc Intervent } \\
\text { Radiol }^{109}\end{array}$ & 65 & $\begin{array}{l}\text { Histopathology. } \\
\text { Bacteriological }\end{array}$ & $\begin{array}{l}\text { Distribution of } \\
\text { RBCs, PLTs, and } \\
\text { WBCs. Bacteria } \\
\text { presence }\end{array}$ & $\begin{array}{l}\text { CE (38), non-CE or } \\
\text { CRY (27) }\end{array}$ & $\begin{array}{l}\text { Gram-positive bacteria in four thrombi: infective } \\
\text { endocarditis (2), urinary tract infection (1), and } \\
\text { pneumonia (1) }\end{array}$ \\
\hline $\begin{array}{l}\text { Itsekson Hayosh et al. (2020) } \\
\text { J Neurolnterv Surg }\end{array}$ & 68 & Biochemical & $\begin{array}{l}\text { Eluted thrombin } \\
\text { activity (ETA) }\end{array}$ & $\begin{array}{l}\text { LAA (15), CE (18), } \\
\text { ODC (18), and CRY } \\
(17)\end{array}$ & $\begin{array}{l}\text { Temporal profile of ETA similar in CRY and CE, and } \\
\text { different from LAA }\end{array}$ \\
\hline Juega et al. (2019) Stroke ${ }^{120}$ & 40 & Flow cytometry & $\begin{array}{l}\text { Leukocyte } \\
\text { populations }\end{array}$ & $\mathrm{LAA}, \mathrm{CE}$, and $\mathrm{ODC}$ & $\begin{array}{l}\text { Higher proportion of CD4 T lymphocytes in LAA } \\
(24.85 \%) \text { than in CE (15.83\%). Higher proportion of } \\
\text { natural killer (NK) cells in LAA ( } 21.08 \%) \text { than in CE } \\
(17.04 \%) \text {. Lower proportion of CD8 T lymphocytes in } \\
\text { LAA }(13.56 \%) \text { than in CE }(20.24 \%)\end{array}$ \\
\hline $\begin{array}{l}\text { Kim et al. (2020) } \\
\text { J Clin Neurosci }{ }^{51}\end{array}$ & 52 & Histopathology & $\begin{array}{l}\text { RBC, FBR, and PLTs } \\
\text { proportions. PLT } \\
\text { distribution } \\
\text { pattern (PDP) }\end{array}$ & $\begin{array}{l}\text { LAA (10), CE (31), } \\
\text { and CRY (11) }\end{array}$ & $\begin{array}{l}\text { Mostly peripheral PDP in LAA (70\%). Mostly clustering } \\
\text { PDP in CE (77.4\%). Similar PDPs in CE and CRY. }\end{array}$ \\
\hline $\begin{array}{l}\text { Kim et al. (2015) } \\
\text { Am J Neuroradiol }\end{array}$ & 37 & Histopathology & $\begin{array}{l}\text { RBC, FBR, PLTs, } \\
\text { and WBC } \\
\text { proportions }\end{array}$ & $\begin{array}{l}\text { LAA (8), CE (22), } \\
\text { and CRY (7) }\end{array}$ & $\begin{array}{l}\text { Higher RBC proportion in CE }(37.8 \%) \text { than in LAA } \\
(16.9 \%) \text {. Lower FBR proportion in CE }(32.3 \%) \text { than in } \\
\text { LAA (48.5\%) }\end{array}$ \\
\hline $\begin{array}{l}\text { Laridan et al. (2017) } \\
\text { Ann Neurol }\end{array}$ & 68 & Histopathology & $\begin{array}{l}\text { NETs (H3Cit) } \\
\text { proportion }\end{array}$ & $\begin{array}{l}\text { LAA (7), CE (40), } \\
\text { ODC (6), and CRY } \\
(15)\end{array}$ & $\begin{array}{l}\text { Nearly double amount of NETs in CE }(3.07 \% \pm 2.21 \%) \\
\text { than non-CE (LAA+ODC; } 1.57 \% \pm 1.23 \%)\end{array}$ \\
\hline $\begin{array}{l}\text { Liao et al }(2020) \\
\text { Front Neurol }{ }^{123}\end{array}$ & 88 & Histopathology & $\begin{array}{l}\text { RBC, FBR, and PLTs } \\
\text { proportions. WBC } \\
\text { count }\end{array}$ & $\begin{array}{l}\text { LAA (25), CE (46), } \\
\text { ODC (6), and CRY } \\
(11)\end{array}$ & $\begin{array}{l}\text { Higher RBC proportion (range) in LAA }(53.44 \% \\
[49.91 \%-56.97 \%]) \text { than in CE }(35.70 \%[32.04 \%- \\
39.36 \%]) \text { or CRY }(38.18 \% \text { [ } 31.01 \%-45.35 \%]) \text {. Higher } \\
\text { FBR proportion in both CE }(35.91 \%[31.44 \%-40.39 \%]) \\
\text { and CRY }(39.73 \%[27.97 \%-51.49 \%]) \text { than in LAA } \\
(22.96 \%[17.81 \%-28.11 \%]) \text { or ODC }(26.33 \%[12.31 \%- \\
40.36 \%]) \text {. }\end{array}$ \\
\hline $\begin{array}{l}\text { Maekawa et al. (2018) } \\
\text { Cerebrovasc Dis Extra }\end{array}$ & 43 & Histopathology & $\begin{array}{l}\text { RBC, FBR, and } \\
\text { WBC proportions }\end{array}$ & $\begin{array}{l}\text { LAA (5), CE (30), } \\
\text { ODC (1), and CRY } \\
\text { (7) }\end{array}$ & $\begin{array}{l}\text { Lower RBC proportion in CE }(29.5 \% \pm 26.2 \%) \text { than in } \\
\text { non-CE }(49.6 \% \pm 26.1 \%) \text {. Higher FBR proportion in CE } \\
(66.2 \% \pm 25.8 \%) \text { than in non-CE }(46.4 \% \pm 25.5 \%) \text {. }\end{array}$ \\
\hline Marder et al. (2006) Stroke & 25 & Histopathology & $\begin{array}{l}\text { Distribution of } \\
\text { RBCs, PLTs, and } \\
\text { WBCs. Fungi } \\
\text { presence }\end{array}$ & $\begin{array}{l}\text { LAA (4), CE (16), } \\
\text { ODC (3), and CRY } \\
\text { (2) }\end{array}$ & $\begin{array}{l}\text { One mycotic thrombus. Aortic valve infective } \\
\text { endocarditis }\end{array}$ \\
\hline $\begin{array}{l}\text { Mereuta et al. (2020) } \\
\text { Stroke }^{100}\end{array}$ & 79 & Histopathology & WWF proportion & $\begin{array}{l}\text { LAA (13), CE (39), } \\
\text { ODC (12), and CRY } \\
\text { (15) }\end{array}$ & Higher WWF proportion in CRY when compared to CE \\
\hline
\end{tabular}


Supplementary Table 2. Continued

\begin{tabular}{|c|c|c|c|c|c|}
\hline Study & $\begin{array}{l}\text { Sample size } \\
\text { (clots/ } \\
\text { patients) }\end{array}$ & Analysis & $\begin{array}{l}\text { Thrombus } \\
\text { composition items }\end{array}$ & $\begin{array}{l}\text { Etiology groups } \\
\text { (patients) }\end{array}$ & $\begin{array}{l}\text { Association composition-etiology or } \\
\text { underlying pathology }\end{array}$ \\
\hline $\begin{array}{l}\text { Niesten et al. (2014) } \\
\text { PLOS One }\end{array}$ & 22 & Histopathology & $\begin{array}{l}\text { RBC, FBR, and } \\
\text { PLTs proportions }\end{array}$ & $\begin{array}{l}\text { LAA (8), CE (6), ODC } \\
\text { (3), and CRY (5) }\end{array}$ & $\begin{array}{l}\text { Higher RBC proportion (range) in both LAA (50\% [35\%- } \\
90 \%]) \text { and ODC (35\% [20\%-40\%]), than in CE (35\% } \\
\text { [5\%-45\%]) or CRY }(25 \%[2 \%-40 \%])\end{array}$ \\
\hline $\begin{array}{l}\text { Nouh et al. (2020) } \\
\text { BMC Neurology }\end{array}$ & 33 & Histopathology & $\begin{array}{l}\text { RBC and PLTs } \\
\text { proportions. RBC/ } \\
\text { PLTs ratio }\end{array}$ & $\begin{array}{l}\text { LAA (9), CE (14), } \\
\text { ODC (4), and ESUS } \\
\text { (6) }\end{array}$ & $\begin{array}{l}\text { RBC/PLTs ratio in ESUS }(0.36 \pm 0.33) \text { similar to CE } \\
(0.78 \pm 0.65) \text {, and different from LAA }(1.73 \pm 2.38) \text { or } \\
\text { ODC }(1.44 \pm 0.70)\end{array}$ \\
\hline $\begin{array}{l}\text { Novotny et al. (2020) } \\
\text { Neurology }{ }^{66}\end{array}$ & 71 & Histopathology & $\begin{array}{l}\text { FBR and PLTs } \\
\text { proportions. WBC } \\
\text { subtypes counts. } \\
\text { NETs and H3Cit } \\
\text { counts }\end{array}$ & $\begin{array}{l}\text { LAA (15), CE (35), } \\
\text { and CRY (21) }\end{array}$ & $\begin{array}{l}\text { Lower NETs count and netting neutrophils rate in LAA } \\
\text { than in CE or CRY. }\end{array}$ \\
\hline $\begin{array}{l}\text { Park et al. (2019) } \\
\text { Ann Neurol }{ }^{65}\end{array}$ & 48 & Histopathology & $\begin{array}{l}\text { RBC, FBR, and PLTs } \\
\text { proportions. } \\
\text { Neutrophil and } \\
\text { NETs counts }\end{array}$ & $\begin{array}{l}\text { S Control (16), AC } \\
\text { (16), and IC (16) }\end{array}$ & $\begin{array}{l}\text { Higher PLT proportion in AC ( } 43.2 \%) \text { than in IC (12.9\%) } \\
\text { or control (14.1\%). Lower RBC proportion in AC (3.4\%) } \\
\text { than in IC }(43.5 \%) \text { or control }(40.7 \%)\end{array}$ \\
\hline $\begin{array}{l}\text { Sgreccia et al. (2019) } \\
\text { J Neurolntervent Surg } \\
36\end{array}$ & 255 & Macroscopic & $\begin{array}{l}\text { Visual aspect: } \\
\text { red/black or } \\
\text { white }\end{array}$ & $\begin{array}{l}\text { LAA (53), CE (127), } \\
\text { ODC (13), CRY (45), } \\
\text { and atypical (17) }\end{array}$ & $\begin{array}{l}\text { Atypical etiologies (AC, IE, etc.) more frequent in white } \\
\text { clots }(27.3 \%) \text { than red/black clots }(4.7 \%)\end{array}$ \\
\hline Shin et al. (2018) PLOS One $e^{84}$ & $93 / 37$ & Histopathology & $\begin{array}{l}\mathrm{RBC}, \mathrm{FP} \text {, and } \mathrm{WBC} \\
\text { proportions }\end{array}$ & $\begin{array}{l}\text { LAA (7), CE (22), } \\
\text { and CRY (8) }\end{array}$ & $\begin{array}{l}\text { Higher RBC proportion in CE }(38 \%) \text { than in LAA }(23 \%) \\
\text { or CRY ( } 26 \%) \text {. Lower WBC proportion in CE }(3 \%) \text { than } \\
\text { in LAA }(6 \%) \text { or CRY (5\%) }\end{array}$ \\
\hline Sporns et al. (2017) Stroke ${ }^{96}$ & 187 & Histopathology & $\begin{array}{l}\mathrm{RBC}, \mathrm{FBR} \text {, and } \\
\mathrm{WBC} \text { proportions }\end{array}$ & $\begin{array}{l}\text { LAA (35), CE (77), } \\
\text { ODC (11), and CRY } \\
(64)\end{array}$ & $\begin{array}{l}\text { Composition (range) in both CE (RBC 28.0\% [11.0\%- } \\
53.0 \%], \text { FBR 60.0\% [40.0\%-80.0\%], and WBC 8.0\% } \\
\text { [5.0\%-12.5\%]) and CRY (RBC 26.0\% [10.5\%-43.5\%], FBR } \\
63.5 \% \text { [45.5\%-77.8\%], and WBC 10.0\% [5.0\%-14.5\%]) } \\
\text { different from non-CE (LAA+ODE) (RBC 42.0\% [20.9\%- } \\
71.8 \%] \text {, FBR 51.5\% [19.5\%-68.5\%], and WBC 5.0\% } \\
\text { [4.0\%-10.0\%]). Similar composition in and in CE and CRY }\end{array}$ \\
\hline $\begin{array}{l}\text { Wolpert et al. (2020) } \\
\text { Eur J Neurol }{ }^{129}\end{array}$ & 32 & Histopathology & $\begin{array}{c}\text { Tumor cell } \\
\text { presence }\end{array}$ & $\begin{array}{l}\text { AC: LAA (4), CE (8), } \\
\text { ODC (1), and CRY } \\
\text { (19) }\end{array}$ & Tumor cells in one out of 32 with $\mathrm{AC}(3.1 \%)$ \\
\hline $\begin{array}{l}\text { Xue et al. (2018) } \\
\text { Natl Med J China }{ }^{124}\end{array}$ & 58 & Histopathology & $\begin{array}{c}\mathrm{RBC} \text { and } \mathrm{FBR} \\
\text { proportions }\end{array}$ & $\begin{array}{l}\text { LAA (17), CE (31), } \\
\text { and CRY (10) }\end{array}$ & $\begin{array}{l}\text { Higher RBC proportion in LAA (58\%) than in CE (46\%), } \\
\text { and higher FBR proportion in CE (54\%) than in LAA } \\
(42 \%) \text {. Similar composition in CE (RBC 46\%, FBR 54\%) } \\
\text { and CRY (RBC } 47 \% \text {, FBR 53\%) }\end{array}$ \\
\hline $\begin{array}{l}\text { Ye et al. (2020) } \\
\text { Interv Neuroradiol }{ }^{55}\end{array}$ & 52 & Histopathology & $\begin{array}{l}\text { RBC, FBR, and PLT } \\
\text { proportions. WWF } \\
\text { content }\end{array}$ & $\begin{array}{l}\text { LAA (12), CE (34), } \\
\text { and CRY (6). NG } \\
\text { (26) and DM (26) }\end{array}$ & $\begin{array}{l}\text { Lower RBC proportion in DM }(26.0 \%) \text { than in NG } \\
(42.9 \%) . \text { Higher FBR proportion in DM }(44.2 \%) \text { than in } \\
\text { NG }(28.3 \%)\end{array}$ \\
\hline
\end{tabular}

TOAST, Trial of Org 10172 in Acute Stroke Treatment; RBC, red blood cell; FBR, fibrin; LAA, large-artery atherosclerosis (TOAST 1); CE, cardioembolism (TOAST 2); CRY, cryptogenic stroke of undetermined etiology (TOAST 5); RTqPCR, reverse transcriptase quantitative polymerase chain reaction; IL-1 $\beta$, interleukin-1 $\beta$; FP, fibrin+platelet; ODC, stroke of other determined cause (TOAST 4); WBC, white blood cell; PLT, platelet; NET, neutrophil extracellular trap; NG, normoglycemia; $\mathrm{H} 3 \mathrm{Cit}$, citrullinated histone $\mathrm{H3}$; $\mathrm{AHG}$, acute hyperglycemia; DM, diabetes mellitus; ESUS, embolic stroke of undetermined cause; ECA, extracted clot area; $A C$, active cancer; VWF, von Willebrand factor; IC, inactive cancer; IE, infective endocarditis. 
Supplementary Table 3. Case reports: thrombus/embolus composition and stroke etiologies or underlying pathologies

\begin{tabular}{|c|c|c|c|c|c|}
\hline Study & Case(s) presentation & $\begin{array}{l}\text { Thrombus/ } \\
\text { embolus analysis }\end{array}$ & $\begin{array}{l}\text { Thrombus/ } \\
\text { embolus composition }\end{array}$ & Further diagnostic work-up & $\begin{array}{c}\text { Stroke cause/ } \\
\text { underlying pathology }\end{array}$ \\
\hline $\begin{array}{l}\text { Abdel-Wahed et al. (2019) } \\
\text { Am J Med }{ }^{14}\end{array}$ & $\begin{array}{l}\text { A 72-year-old woman. } \\
\text { Bioprosthetic aortic valve. } \\
\text { Suspected urosepsis }\end{array}$ & Histopathology & $\begin{array}{l}\text { Gram-positive } \\
\text { cocci in chains }\end{array}$ & $\begin{array}{l}\text { Streptococcus viridans in } \\
\text { blood cultures. Klebsiella in } \\
\text { urine cultures. Vegetations } \\
\text { on the prosthetic aortic valve }\end{array}$ & $\begin{array}{l}\text { Septic embolus. } \\
\text { Infective endocarditis }\end{array}$ \\
\hline $\begin{array}{l}\text { Ambrosioni et al. (2018) } \\
\text { Clin Infect Dis }{ }^{131}\end{array}$ & $\begin{array}{l}\text { Six cases. Pre- or post-stroke } \\
\text { infective endocarditis. Prosthetic } \\
\text { or native valves }\end{array}$ & $\begin{array}{l}\text { Molecular } \\
\text { biology }\end{array}$ & Streptococcus & $\begin{array}{l}\text { Staphylococcus or } \\
\text { Streptococcus in blood } \\
\text { cultures in four cases }\end{array}$ & $\begin{array}{l}\text { Septic embolus. } \\
\text { Infective endocarditis }\end{array}$ \\
\hline $\begin{array}{l}\text { Anuwatworn et al. (2015) } \\
\text { JACC Cardiovasc Interv }{ }^{24}\end{array}$ & $\begin{array}{l}\text { A 78-year-old man. } \\
\text { Transcatheter aortic valve } \\
\text { replacement (TAVR) }\end{array}$ & $\begin{array}{l}\text { Macroscopic. } \\
\text { Histopathology }\end{array}$ & Heart valve tissue & $\begin{array}{l}\text { Aortic valve echo-dense } \\
\text { mobile mass disappearing } \\
\text { after TAVR }\end{array}$ & $\begin{array}{l}\text { Cardiac valve tissue } \\
\text { embolization }\end{array}$ \\
\hline $\begin{array}{l}\text { Bain et al. (2011) J } \\
\text { Neuroimaging }^{132}\end{array}$ & $\begin{array}{l}\text { A 24-year-old female. Left } \\
\text { ventricular assist device (LVAD). } \\
\text { Epidermidis, septicemia and } \\
\text { persistent infections of the } \\
\text { LVAD }\end{array}$ & Histopathology & $\begin{array}{l}\text { Gram-positive } \\
\text { cocci and bacilli }\end{array}$ & & $\begin{array}{l}\text { Septic embolus. } \\
\text { Infective endocarditis }\end{array}$ \\
\hline $\begin{array}{l}\text { Bhaskar et al. (2019) } \\
\text { Can J Neurol Sci }{ }^{102}\end{array}$ & $\begin{array}{l}\text { Four cases. Prosthetic valves. } \\
\text { History of infective endocarditis } \\
\text { in two cases }\end{array}$ & Histopathology & $\begin{array}{l}\text { Fibrinoid material } \\
\text { with clusters of } \\
\text { bacterial cocci }\end{array}$ & $\begin{array}{l}\text { Prosthetic valve vegetations. } \\
\text { Enterococcus faecalis and } \\
\text { Staphylococcus aureus in } \\
\text { blood culture in two cases }\end{array}$ & $\begin{array}{l}\text { Septic embolus. } \\
\text { Infective endocarditis }\end{array}$ \\
\hline $\begin{array}{l}\text { Biraschi et al. (2016) } \\
\text { J Stroke Cerebrovasc Dis }\end{array}$ & $\begin{array}{l}\text { A 75-year-old man. Hypertension } \\
\text { and atrial fibrillation }\end{array}$ & $\begin{array}{l}\text { Macroscopic. } \\
\text { Histopathology }\end{array}$ & $\begin{array}{l}\text { White-pink hard } \\
\text { tissue-like } \\
\text { material. Papillary } \\
\text { fronds, } \\
\text { endothelium and } \\
\text { elastic fibers }\end{array}$ & & $\begin{array}{l}\text { Cardiac embolic } \\
\text { papillary fibroelastoma }\end{array}$ \\
\hline $\begin{array}{l}\text { Chapot et al. (2006) } \\
\text { Am J Neuroradiol }{ }^{25}\end{array}$ & $\begin{array}{l}\text { A 43-year-old woman. } \\
\text { Endovascular intracranial } \\
\text { aneurysm treatment }\end{array}$ & $\begin{array}{l}\text { Macroscopic. } \\
\text { Histopathology }\end{array}$ & $\begin{array}{l}\text { Cotton-like } \\
\text { synthetic fibers }\end{array}$ & & $\begin{array}{l}\text { Inadvertent } \\
\text { embolization of foreign } \\
\text { bodies }\end{array}$ \\
\hline $\begin{array}{l}\text { Distefano et al. (2019) } \\
\text { J Stroke Cerebrovasc Dis }{ }^{133}\end{array}$ & $\begin{array}{l}\text { A 75-year-old man. } \\
\text { Hypertension. Suspected } \\
\text { infection }\end{array}$ & Histopathology & $\begin{array}{l}\text { Necrotic material } \\
\text { and bacterial } \\
\text { colonies }\end{array}$ & $\begin{array}{l}\text { Vegetation in aortic valve. } E \\
\text { nterococcus faecalis in blood } \\
\text { cultures }\end{array}$ & $\begin{array}{l}\text { Septic embolus. } \\
\text { Infective endocarditis }\end{array}$ \\
\hline $\begin{array}{l}\text { Elodie et al. (2019) } \\
\text { J Neurol Scii }\end{array}$ & $\begin{array}{l}\text { A 70-year-old woman. Mitral } \\
\text { stenosis and atrial fibrillation }\end{array}$ & $\begin{array}{l}\text { Macroscopic. } \\
\text { Histopathology. } \\
\text { Molecular } \\
\text { biology }\end{array}$ & $\begin{array}{l}\text { Tropheryma } \\
\text { whipplei DNA } \\
\text { sequences }\end{array}$ & $\begin{array}{l}\text { Negative blood culture. } \\
\text { Cleared previous suspected } \\
\text { small aortic vegetation }\end{array}$ & $\begin{array}{l}\text { Septic embolus. } \\
\text { Whipple's endocarditis }\end{array}$ \\
\hline $\begin{array}{l}\text { Fassa et al. (2014) } \\
\text { Circ Cardiovasc Interv }{ }^{27}\end{array}$ & A 90-year-old woman. TAVR & $\begin{array}{l}\text { Macroscopic. } \\
\text { Histopathology }\end{array}$ & Calcific & & $\begin{array}{l}\text { Detached aortic valve or } \\
\text { aortic wall calcification }\end{array}$ \\
\hline $\begin{array}{l}\text { Fitzpatrick et al. (2018) } \\
\text { J Neurolnterv Surg }\end{array}$ & $\begin{array}{l}\text { Three cases. History of deep vein } \\
\text { thrombosis }\end{array}$ & $\begin{array}{l}\text { Macroscopic. } \\
\text { Histopathology }\end{array}$ & $\begin{array}{l}\text { Elongated, pale- } \\
\text { colored clot }\end{array}$ & $\begin{array}{l}\text { Carotid free-floating } \\
\text { thrombus (FFT) }\end{array}$ & FFT embolism \\
\hline $\begin{array}{l}\text { Garcia-Ptacek et al. (2014) } \\
\text { J Neurolnterv Surg }\end{array}$ & $\begin{array}{l}\text { Two cases. Concomitant } \\
\text { peripheral thrombi }\end{array}$ & Histopathology & $\begin{array}{l}\text { Myxomatous } \\
\text { material }\end{array}$ & $\begin{array}{l}\text { Echocardiographic mobile } \\
\text { mass }\end{array}$ & $\begin{array}{l}\text { Cardiac myxoma } \\
\text { embolism }\end{array}$ \\
\hline $\begin{array}{l}\text { Genchi et al. (2020) } \\
\text { J Neurol Scio }\end{array}$ & $\begin{array}{l}\text { An 84-year-old man. Atrial } \\
\text { fibrillation and uncomplicated } \\
\text { carotid plaques }\end{array}$ & $\begin{array}{l}\text { Macroscopic. } \\
\text { Histopathology }\end{array}$ & $\begin{array}{l}\text { Reddish tissue } \\
\text { with white } \\
\text { inclusions. } \\
\text { Organized } \\
\text { calcified } \\
\text { thrombus }\end{array}$ & $\begin{array}{l}\text { Hyperechoic aortic valve } \\
\text { calcification }\end{array}$ & $\begin{array}{l}\text { Dislodged aortic valve } \\
\text { calcification }\end{array}$ \\
\hline $\begin{array}{l}\text { Hinman et al. (2013) } \\
\text { Front Neurol }\end{array}$ & $\begin{array}{l}\text { A 28-year-old male. Retinal } \\
\text { surgery and post-operative neck } \\
\text { compression }\end{array}$ & $\begin{array}{l}\text { Macroscopic. } \\
\text { Proteomics }\end{array}$ & $\begin{array}{l}96 \% \text { Common } \\
\text { proteins }\end{array}$ & $\begin{array}{l}\text { Tandem cervical and } \\
\text { intracranial occlusions }\end{array}$ & $\begin{array}{l}\text { Traumatic carotid } \\
\text { thrombosis and } \\
\text { embolization }\end{array}$ \\
\hline $\begin{array}{l}\text { Kan et al. (2012) } \\
\text { World Neurosurg }\end{array}$ & $\begin{array}{l}\text { A 78-year-old woman. Mitral } \\
\text { valve prolapse. Suspected } \\
\text { infection }\end{array}$ & $\begin{array}{l}\text { Macroscopic. } \\
\text { Bacteriological }\end{array}$ & $\begin{array}{l}\text { Positive for } \\
\text { viridans } \\
\text { streptococci }\end{array}$ & $\begin{array}{l}\text { Large, mobile vegetation on } \\
\text { the aortic valve. Positive } \\
\text { blood cultures }\end{array}$ & $\begin{array}{l}\text { Septic embolus. } \\
\text { Infective endocarditis }\end{array}$ \\
\hline $\begin{array}{l}\text { Katano et al. (2020) } \\
\text { Clin Neurol }^{137}\end{array}$ & An 88-year-old man & Histopathology & Aspergillus fungus & Paranasal sinus invasion & Septic embolus. Sinusitis \\
\hline
\end{tabular}


Supplementary Table 3. Continued

\begin{tabular}{|c|c|c|c|c|c|}
\hline Study & Case(s) presentation & $\begin{array}{l}\text { Thrombus/ } \\
\text { embolus analysis }\end{array}$ & $\begin{array}{l}\text { Thrombus/ } \\
\text { embolus composition }\end{array}$ & Further diagnostic work-up & $\begin{array}{c}\text { Stroke cause/ } \\
\text { underlying pathology }\end{array}$ \\
\hline $\begin{array}{l}\text { Kim et al. (2014) } \\
\text { Neurointervention }{ }^{32}\end{array}$ & $\begin{array}{l}\text { A 40-year-old woman. Fever, } \\
\text { malaise and systolic murmur }\end{array}$ & Histopathology & $\begin{array}{l}\text { Gram-positive } \\
\text { cocci }\end{array}$ & $\begin{array}{l}\text { Mitral valve vegetation. Blood } \\
\text { cultures positive for } \\
\text { Streptococcus mitis }\end{array}$ & $\begin{array}{l}\text { Septic embolus. } \\
\text { Infective endocarditis }\end{array}$ \\
\hline $\begin{array}{l}\text { Koneru et al. (2021) } \\
\text { J Neurolnterv Surg }\end{array}$ & $\begin{array}{l}\text { Three cases. Aged } 41-55 \text { years. } \\
\text { Few to no vascular risk factors }\end{array}$ & Histopathology & $\begin{array}{l}\text { Fresh appearance. } \\
\text { Usual RBC, FBR, } \\
\text { and WBC } \\
\text { contents }\end{array}$ & $\begin{array}{l}\text { Ipsilateral angiographic } \\
\text { carotid web (CaW). No } \\
\text { superimposed thrombus }\end{array}$ & Embolization from CaW \\
\hline $\begin{array}{l}\text { Matsumoto et al. (2016) } \\
\text { J Stroke Cerebrovasc Dis }{ }^{33}\end{array}$ & Two cases. Active cancer & $\begin{array}{l}\text { Macroscopic. } \\
\text { Histopathology }\end{array}$ & $\begin{array}{l}\text { White and solid. } \\
\text { Fibrin }>90 \% \text {. No } \\
\text { tumor cells }\end{array}$ & $\begin{array}{l}\text { Cancer-related } \\
\text { hypercoagulation }\end{array}$ & $\begin{array}{l}\text { Trousseau syndrome- } \\
\text { related } \\
\text { thromboembolism }\end{array}$ \\
\hline $\begin{array}{l}\text { Matsumoto et al. (2020) } \\
\text { J Stroke Cerebrovasc Dis }{ }^{139}\end{array}$ & $\begin{array}{l}\text { A 67-year-old man. History of } \\
\text { dyslipidemia, taking statins, and } \\
\text { smoking }\end{array}$ & Histopathology & $\begin{array}{l}\text { Small calcification } \\
\text { and a cholesterol } \\
\text { crystal cleft }\end{array}$ & $\begin{array}{l}\text { Atheromatous lesion at the } \\
\text { aortic arch }\end{array}$ & $\begin{array}{l}\text { Aortogenic embolic } \\
\text { stroke }\end{array}$ \\
\hline $\begin{array}{l}\text { Nakanishi et al. (2018) } \\
\text { Clin Neurol }{ }^{134}\end{array}$ & $\begin{array}{l}\text { An 80-year-old woman. } \\
\text { Suspected infection }\end{array}$ & $\begin{array}{l}\text { Macroscopic. } \\
\text { Histopathology }\end{array}$ & $\begin{array}{l}\text { White thrombus. } \\
\text { Gram-positive } \\
\text { cocci }\end{array}$ & $\begin{array}{l}\text { Negative blood culture and } \\
\text { echocardiogram }\end{array}$ & $\begin{array}{l}\text { Septic embolus. } \\
\text { Infective endocarditis }\end{array}$ \\
\hline $\begin{array}{l}\text { Pisano et al. (2020) } \\
\text { J Stroke Cerebrovasc Dis }{ }^{34}\end{array}$ & $\begin{array}{l}\text { A 33-year-old. Exposure to a } \\
\text { COVID-19 positive relative }\end{array}$ & Macroscopic & $\begin{array}{l}\text { Over } 50 \mathrm{~mm} \text { in } \\
\text { length }\end{array}$ & $\begin{array}{l}\text { SARS-CoV-2 positive. } \\
\text { Hypercoagulability }\end{array}$ & $\begin{array}{l}\text { Thromboembolism } \\
\text { secondary to COVID-19 }\end{array}$ \\
\hline $\begin{array}{l}\text { Salam et al. (2018) } \\
\text { J Stroke Cerebrovasc Dis }{ }^{16}\end{array}$ & $\begin{array}{l}\text { A } 25 \text {-year-old woman. No } \\
\text { vascular risk factors. }\end{array}$ & $\begin{array}{l}\text { Macroscopic. } \\
\text { Histopathology }\end{array}$ & $\begin{array}{l}\text { Pale, white soft } \\
\text { material. Papillary } \\
\text { neoplasm with } \\
\text { hyalinized cores } \\
\text { lined by } \\
\text { endothelium }\end{array}$ & & $\begin{array}{l}\text { Cardiac embolic } \\
\text { papillary fibroelastoma }\end{array}$ \\
\hline $\begin{array}{l}\text { Salinas et al. (2013) } \\
\text { JACC Cardiovasc Interv }{ }^{17}\end{array}$ & $\begin{array}{l}\text { An 88-year-old woman. } \\
\text { Transcatheter aortic valve } \\
\text { implantation (TAVI) }\end{array}$ & Macroscopic & Red-dark & $\begin{array}{l}\text { Ventricular echo-dense } \\
\text { mobile mass disappearing } \\
\text { after TAVI }\end{array}$ & $\begin{array}{l}\text { Catheter-related } \\
\text { thromboembolism }\end{array}$ \\
\hline $\begin{array}{l}\text { Scharf et al. (2016) } \\
\text { Neurocrit Care }{ }^{138}\end{array}$ & $\begin{array}{l}\text { A 56-year-old man. } \\
\text { Immunocompromised }\end{array}$ & Histopathology & $\begin{array}{l}\text { Fungal hyphae of } \\
\text { Zygomycetes } \\
\text { species }\end{array}$ & $\begin{array}{l}\text { Fungal culture of sphenoid } \\
\text { sinus biopsy positive for } \\
\text { Rhizomucor species }\end{array}$ & $\begin{array}{l}\text { Angioinvasive } \\
\text { mucormycosis }\end{array}$ \\
\hline $\begin{array}{l}\text { Scharf et al. (2017) } \\
\text { J Neurolntervent Surg }\end{array}$ & $\begin{array}{l}\text { A middle-aged adult. Mitral valve } \\
\text { replacement and infective } \\
\text { endocarditis }\end{array}$ & $\begin{array}{l}\text { Macroscopic. } \\
\text { Histopathology }\end{array}$ & $\begin{array}{l}\text { Firm and rigid } \\
\text { texture. Hyaline } \\
\text { and coccal forms }\end{array}$ & $\begin{array}{l}\text { Vegetation on both the mitral } \\
\text { valve prosthesis and native } \\
\text { aortic valve }\end{array}$ & $\begin{array}{l}\text { Septic embolus. } \\
\text { Infective endocarditis }\end{array}$ \\
\hline $\begin{array}{l}\text { Semerano et al. (2019) } \\
\text { J Neurol }{ }^{19}\end{array}$ & $\begin{array}{l}\text { An 86-year-old man. Arterial } \\
\text { hypertension }\end{array}$ & $\begin{array}{l}\text { Macroscopic. } \\
\text { Histopathology }\end{array}$ & $\begin{array}{l}\text { Solid, yellow with } \\
\text { red spot. Intima } \\
\text { layer, foamy } \\
\text { macrophages, } \\
\text { lymphocytes, } \\
\text { extracellular } \\
\text { matrix, smooth } \\
\text { muscle cells, } \\
\text { cholesterol clefts, } \\
\text { focal hemorrhage } \\
\text { and outer fibrin } \\
\text { cap }\end{array}$ & $\begin{array}{l}\text { Angiographic focal } \\
\text { truncal-type occlusion with } \\
\text { distal anterograde } \\
\text { repermeability in the } \\
\text { cerebral vessel }\end{array}$ & $\begin{array}{l}\text { Intracranial } \\
\text { atherosclerotic plaque }\end{array}$ \\
\hline $\begin{array}{l}\text { Sgreccia et al. (2020) } \\
\text { J Neuroradiol }{ }^{136}\end{array}$ & $\begin{array}{l}\text { A 31-year-old male. Suspected } \\
\text { infection. Aortic murmur }\end{array}$ & $\begin{array}{l}\text { Macroscopic. } \\
\text { Molecular } \\
\text { biology }\end{array}$ & $\begin{array}{l}\text { White-colored. } \\
\text { Candida } \\
\text { parapsilosis }\end{array}$ & $\begin{array}{l}\text { Vegetation in bicuspid aortic } \\
\text { valve. C. parapsilosis } \\
\text { confirmed in blood culture }\end{array}$ & $\begin{array}{l}\text { Septic embolus. Fungal } \\
\text { endocarditis }\end{array}$ \\
\hline $\begin{array}{l}\text { Sukumaran et al. (2012) } \\
\text { Neurol India }{ }^{135}\end{array}$ & $\begin{array}{l}\text { A 33-year-old male. Fever and } \\
\text { malaise. Cardiac murmur }\end{array}$ & Histopathology & $\begin{array}{l}\text { Clusters of } \\
\text { gram-positive } \\
\text { cocci }\end{array}$ & $\begin{array}{l}\text { Mobile mass in mitral valve. } \\
\text { Alpha hemolytic streptococci } \\
\text { in blood culture }\end{array}$ & $\begin{array}{l}\text { Septic embolus. } \\
\text { Infective endocarditis }\end{array}$ \\
\hline $\begin{array}{l}\text { Tejada et al. (2014) } \\
\text { J Neurolntervent Surg }\end{array}$ & $\begin{array}{l}\text { A 64-year-old woman. No } \\
\text { vascular risk factors }\end{array}$ & $\begin{array}{l}\text { Macroscopic. } \\
\text { Histopathology }\end{array}$ & $\begin{array}{l}\text { White soft aspect. } \\
\text { Branching } \\
\text { papillary lesions, } \\
\text { lined by } \\
\text { endothelium }\end{array}$ & & $\begin{array}{l}\text { Cardiac embolic } \\
\text { papillary fibroelastoma }\end{array}$ \\
\hline
\end{tabular}


Supplementary Table 3. Continued

\begin{tabular}{|c|c|c|c|c|c|}
\hline Study & Case(s) presentation & $\begin{array}{l}\text { Thrombus/ } \\
\text { embolus analysis }\end{array}$ & $\begin{array}{c}\text { Thrombus/ } \\
\text { sembolus composition }\end{array}$ & Further diagnostic work-up & $\begin{array}{c}\text { Stroke cause/ } \\
\text { underlying pathology }\end{array}$ \\
\hline $\begin{array}{l}\text { Thomas et al. (2017) } \\
\text { J Neurolnterv Surg }\end{array}$ & $\begin{array}{l}\text { A } 69 \text {-year-old woman. Mitral } \\
\text { valve replacement surgery }\end{array}$ & $\begin{array}{l}\text { Macroscopic. } \\
\text { Histopathology }\end{array}$ & $\begin{array}{l}\text { Tan rubbery object. } \\
\text { Collagen, elastin } \\
\text { and endothelial } \\
\text { cells }\end{array}$ & & $\begin{array}{l}\text { Cardiac chordae } \\
\text { tendineae embolization }\end{array}$ \\
\hline $\begin{array}{l}\text { Usui et al. (2019) } \\
\text { Intern Med }\end{array}$ & $\begin{array}{l}\text { A 91-year-old man. Hypertension } \\
\text { and atrial fibrillation }\end{array}$ & Histopathology & Foamy cells & $\begin{array}{l}\text { Atherosclerotic lesion with } \\
\text { ulceration in the aortic arch }\end{array}$ & $\begin{array}{l}\text { Aortogenic embolic } \\
\text { stroke }\end{array}$ \\
\hline $\begin{array}{l}\text { Valente et al. (2019) } \\
\text { J Clin Neurosci }{ }^{22}\end{array}$ & $\begin{array}{l}\text { A 38-year-old male. Systemic } \\
\text { lupus erythematosus }\end{array}$ & $\begin{array}{l}\text { Macroscopic. } \\
\text { Histopathology }\end{array}$ & $\begin{array}{l}\text { Firm, pale to tan. } \\
\text { Collagenous. IgG, } \\
\text { C1q, C3, and IgA } \\
\text { positive }\end{array}$ & Antiphospholipid syndrome & $\begin{array}{l}\text { Embolism of a } \\
\text { Libman-Sacks } \\
\text { vegetation }\end{array}$ \\
\hline $\begin{array}{l}\text { Wollenweber et al. (2016) } \\
\text { Neurology } y^{23}\end{array}$ & An 80-year-old woman. TAVI & $\begin{array}{l}\text { Macroscopic. } \\
\text { Histopathology }\end{array}$ & $\begin{array}{l}\text { Solid tissue. } \\
\text { Endothelialized, } \\
\text { atherosclerotic } \\
\text { arterial vessel } \\
\text { wall }\end{array}$ & & $\begin{array}{l}\text { Aortic wall fragment } \\
\text { embolization }\end{array}$ \\
\hline
\end{tabular}

RBC, red blood cell; FBR, fibrin; WBC, white blood cell; COVID-19, coronavirus disease 2019; SARS-CoV-2, severe acute respiratory syndrome coronavirus 2; Ig, immunoglobulin. 